Distance entre l'extrémité de millim. millim. médianes et celle des externes ...... . $55 \quad 15$

Longueur du bec depuis la commissure.... $29 \quad 29$

" du tarse ............... 50 51

" du doigt médian sans ongle .... $48 \quad 48$

" de l'ongle médian ........... $16 \quad 12$

", du pouce................. $14 \quad 14$

" de l'ongle postérieur......... $111^{\circ} 10$

Cet oiseau se tient sur les hautes montagnes de la contrée*, habitées aussi par le Megaloperdix caucasicus. II nous reste maintenant à étudier ses habitudes et son aire de dispersion.

Je saisis avec plaisir cette occasion pour rendre hommage à mon ami Louis Mlokosiewicz, qui avec une persévérance digne d'admiration ne cesse de recueillir dans la Géorgie Russe, au milieu de mille difficultés, tout ce qui peut enrichir le domaine de l'histoire naturelle, et qui a si justement apprécié, après l'avoir découvert, les caractères spécifiques du bel oiseau que je viens de décrire.

April 6, 1875.

Dr. E. Hamilton, V.P., in the Chair.

A letter was read from Dr. G. Hartlaub, F.M.Z.S., in which he stated that Dr. Finsch and he had come to the conclusion, from the study of additional examples, that Lobiospiza notabilis (the supposed new Finch from the Navigator Islands), described and figured by them in the Society's 'Proceedings' for 1870 (p. 817, pl. xlix.) from a single specimen in spirits, was probably only the young bird of Amblyura cyanovirens.

Mr. A. G. Butler, F.Z.S., read a " Revision of the Heterocerous Lepidoptera of the family Sphingida." This memoir will be printed in the Society's 'Transactions.'

Mr. Osbert Salvin, F.R.S., read a memoir on the Avifauna of the Galapagos archipelago, of which the following is an abstract.

The Galapagos archipelago consists of a group of fifteen islands, together with a number of outlying rocks. Of the former, seven are considerably larger than the rest, one of them, Albemarle, being as large as all the others put together. The group is situated about 600 miles from the west coast of Ecuador, and lies under the equator.

All the islands are of volcanic origin, the number of craters being computed to be as many as 2000 . The most western of the islands, * Montagne de Bogosch aux environs de Zakataly, non loin de la route de
Tiflis à Derbent, $42^{\circ}$ lat. bor., $111^{\circ}$ long. de Ferro. 
Narborough, as well as Albemarle, is frequently the scene of violent volcanic eruptions-Narborough being from this cause almost entirely devoid of vegetation, its surface presenting vast fields of lava and volcanic scoriæ.

The vegetation in these islands is nowhere dense, but is more luxuriant in the eastern and central islands, especially in the higher grounds inland. These, being usually enveloped in clouds, are damp, and thus foster a richer vegetation than the low-lying lands adjoining the sea-coast.

The clirnate of the archipelago is mild, owing to the influence of the great south polar current which passes through it. Little rain falls except during the months of November, December, and January; consequently there is a great scarcity of water during the rest of the year-so much so, that water is only to be found, near the sea, during the whole year, in one place in Chatham Island. In the interior of the islands perennial pools exist.

The islands appear to have been first discovered by the Spaniards in the 16 th century ; but the exact date is not known. The name Galapagos Islands, derived from the abundance of Tortoises found on them, is that under which they appear in a map bearing the date 1592 , and under which they are mentioned in the voyage of Sir Richard Hawkins in 1593. There is no reason to suppose that the Spaniards ever frequented them to any extent. To the buccaneers, who cruised along the western shores of America towards the close of the 17th century, they were a place of constant resort-the great Tortoises, as well as the quantity of Turtle and Fish, providing them with fresh food, of which they often stood in need.

The same abundance of food also attracted the whaling-ships after the buccaneers had disappeared from these coasts. The number of whalers requiring refreshments suggested the attempt at colonizing Charles Island; but with the decline of the Whale-fisheries, both ships and colonists have almost disappeared, and, at the present time, these islands appear to be only visited by a few vessels from the coast of the mainland, some for fishing, others for collecting Orchilla or Archil.

The effects on the birds of the Galapagos Islands of the visits of vessels and the attempts at colonization do not appear to have resulted at present in any great diminution in their numbers; but as pigs and goats, as well as cattle, cats, and dogs, are now established in several of the islands, these can hardly fail ultimately to affect the indigenous avifauna. As regards the Tortoises, the appearance of man in these islands has been very destructive. These animals in some of the islands have been wholly extirpated; and in all the large islands old individuals have been killed off, leaving only smaller individuals to represent them.

The earlier writers on this archipelago make few allusions to the Birds. Some of the larger sea-birds are sometimes mentioned, and the Pigeon seems, from its tameness and from its excellence as food, to have usually attracted attention; but no collection of Birds was made until Mr. Darwin visited the islands during the surveyingvoyage of H.M.S. 'Beagle' in 1835 . A collection of some extent 
was then formed; and from the account given of it by Mr. Gould in the Zoological Society's 'Proceedings,' and by Mr. Darwin in 'The Zoology of the voyage of the 'Beagle,' we have the first introduction to the Birds of the archipelago. Two other considerable collections have been subsequently made-one by the officers of the Swedish frigate 'Eugenies,' and the other by Dr. Habel. A few specimens were also obtained during the voyage of the French ship 'Vénus,' as well as a few by Capt. Kellett and Lieut. Wood in the 'Herald' and 'Pandora.' I also suppose that Prof. Agassiz, during the 'Hassler' expedition, collected birds on these islands; but of them, if they exist, no account has ever yet been published.

Fifty-six species of Birds have been recorded as inhabitants of the Galapagos archipelago: of these about two thirds are peculiar to the group ; the remainder are species of wide range and belong chiefly to families of Sea-Birds and Waders.

The affinity of the Birds of the islands lies entirely with those of the adjoining continent of South America, whether viewed as regards families, genera, or species.

The distribution of the Birds in the different islands still requires investigation. Few species, however, are restricted in their range to one island; and further research will, I think, tend to show that, so far as the Birds are concerned, hardly any indigenous bird will be found ultimately to inhabit one island alone.

One singular feature is especially worthy of notice with respect to the genus of Finches (Geospiza) which frequents the islands. I refer to the remarkable variation observable in the size of these birds, especially as regards their bills. Mr. Darwin was much struck with this circumstance. Individual birds vary to such an extent that I fully believe that a gradual series could be gathered to show that these birds' beaks vary from the size of that of a Hawfinch (Coccothraustes) to that of a Bunting (Emberiza).

Several species have been characterized from the different sizes of bills of these birds ; but were the difference once shown to be capable of being destroyed by the interposition of intermediate specimens, our usual means of defining species would fail, and the result would compel us to unite all under one specific denomination. As Dr. Habel's notes, however, rather tend than otherwise to show that individuals group themselves to some extent with regard to their size, I have thought it best to adhere for the present to the plan adopted by Mr. Gould, and endeavour to differentiate the species described by him. In doing so, however, I feel that I have assigned rather arbitrary specific characters, based on size alone, to some of the so-called species.

Under favourable circumstances for the maintenance of these birds, coupled with a tendency to vary considerably as regards size, natural selection seems to have acted with great laxity in eliminating intermediate forms.

Lastly, I have drawn up a few suggestions to guide future explorers, and have endeavoured to point out as to which islands our knowledge of the avifauna is incomplete or totally wanting. The large island of Albemarle remains practically unexplored. Nothing 
is known of the birds of Narborough Island, though little can be ex pected here from the extreme barrenness of this island. Hood Island offers a better prospect; and Tower Island ought certainly to be visited. Nor ought the smaller islets, such as Barrington Island and Duncan Island, to be omitted when the collector is in search of new ground. The islands already explored are well worthy of further investigation. Of the whole archipelago, Indefatigable Island is the only one where a really extensive series of birds has been obtained, though Dr. Habel's collections from Bindloe and Abingdon islands are by no means small.

In conclusion, I would recommend any one visiting the Galapagos to call at Cocos Island, in N. lat. $5^{\circ} 33^{\prime}$, long. $86^{\circ} 58^{\prime} \mathrm{W}$. At present we only know of one land bird from this well-wooded and well-watered island; and that is a peculiar Cuckoo of an American genus, Coccyzus ferrugineus. A collection made here cannot fail to be of high interest.

Mr. Salvin's Memoir will be printed entire in the Society's 'Transactions.'

The following papers were read:-

1. A Monograph of the Silicen-fibrous Sponges.

By J. S. Bowerbank, LL.D., F.R.S., F.Z.S., \&c.-Part III.*

[Received March 12, 1875.]

(Plates XXXIX. \& XL.)

Farrea Gassioti, Bowerbank.

Sponge cup-shaped, expansive, parietes very thin; pedicel short. Oscula, pores, and dermal membrane unknown. Skeleton siliceofibrous ; fibres cylindrical, furnished more or less with short acutely conical spines; rete rectangulated; areas mostly square; central cauals large and very distinct, not always confluent, frequently two in each fibre. Interstitial spicula rectangulated sexradiate; radii cylindrical, smooth, few in number. Sarcode, dried, dark amberbrown.

Colour, in the dried state, brown?

Hab. West Indies (Capt. Hunter, R.N.).

Examined in the skeleton state.

The type specimen is 9 lines in height. The pedicel does not exceed 2 lines. The cup is partially compressed; it is 1 inch in its greatest marginal diameter, and 8 lines in its smallest breadth. I could not detect the slightest indication of either dermis or oscula. The primary series of skeleton-fibres radiate from the basal portion of the cup, the secondary ones having a circumferential direction at about right angles to the primary ones; they each appear to be as nearly as possible of the same diameter, and to have the central canals and the spination of the fibres equally apportioned. There

* For Part II. see Proc. Zool. Soc. 1869, p. 323. 


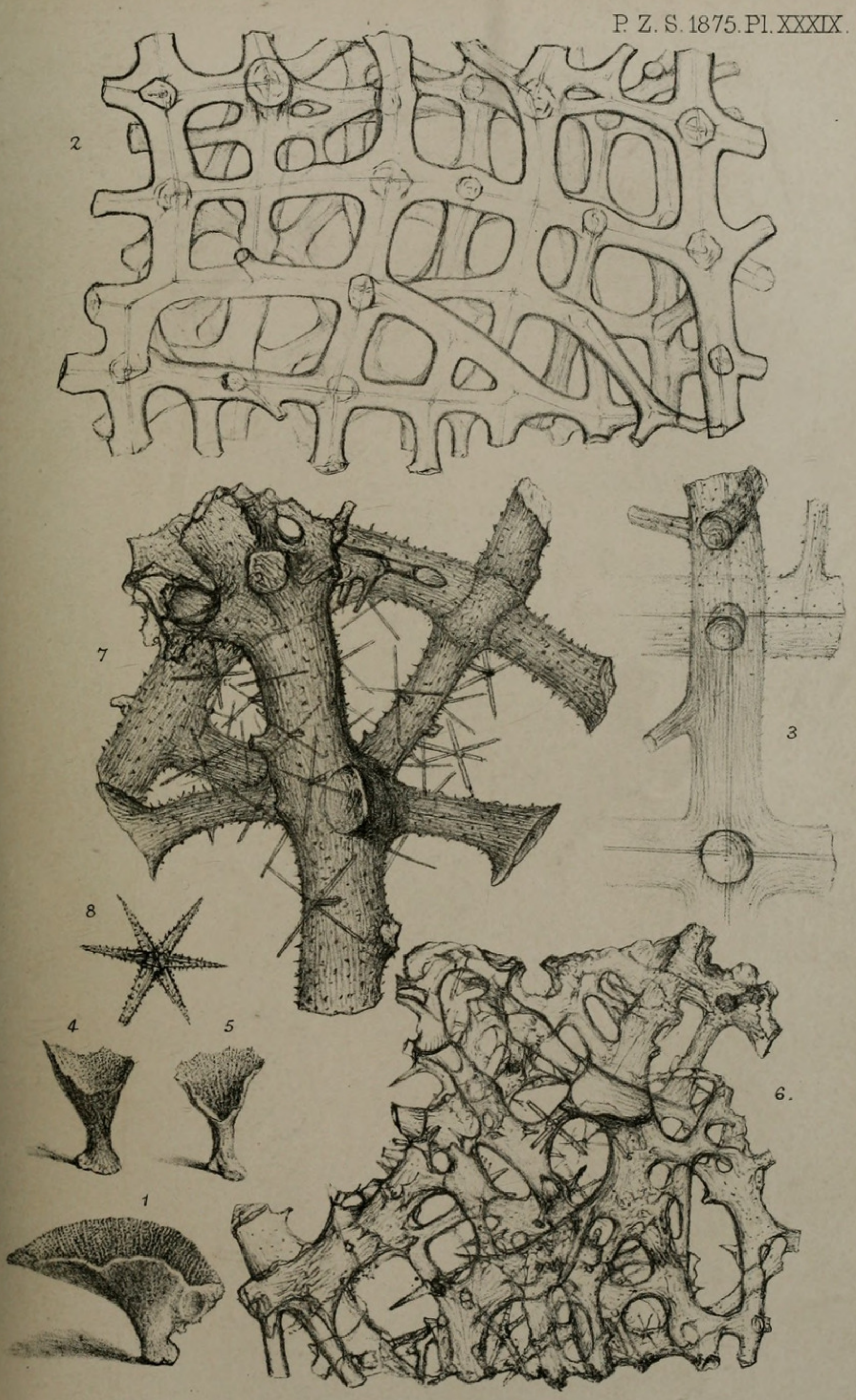

Farrea Gassioti 1-3. F. pocillum 4-8

W. Lens Aldous del et lith. $\quad$ W. West \& Co imp 


are three or more layers of the skeleton-structure. The fibres of the interior of the cup have the greatest number of spines upon them; those of the outer surface appear to be nearly spineless. The spines are acutely conical; their greatest height rarely exceeds their basal diameters. The fibres and the central canals within them both vary to a considerable extent in their diameter. One of the largest fibres measured $\frac{1}{158}$ inch and one of the smallest $\frac{1}{500}$ inch in diameter. The average of three that were measured was $\frac{1}{286}$ inch. One of the largest canals measured $\frac{1}{2308}$ inch in diameter; and a very small one in connexion with the large one was $\frac{1}{750}$ inch, and the average $\frac{1}{4904}$ inch in diameter. There does not appear to exist any definite proportion between the fibre and its central canal, a large canal frequently occurring in a small fibre, and a very slender one in a stout fibre. In their course through the skeleton they usually coalesce at each angle of the rete; but it not unfrequently occurs that large fibres have two eanals running parallel to each other, as if each had originated at opposite angles of the rete; and occasionally one or both terminate in a spherical dilatation. A few of the interstitial spicula fortunately remain entangled in the skeleton-rete. They are small, rectangulated, sexradiate forms, with smooth cylindrical radii, and are all of about the same size. Some portions of the skeleton-fibres were eovered by a very thin layer of sarcode of a bark-brown amber-colour.

The sponge was apparently a skeleton when brought up from the bottom of the sea; but although so many important characters are absent, those available are sufficiently striking to render its discrimination from other nearly allied species satisfactory.

I have named the species after Dr. Gassiot, through whose kindness I have had the opportunity of examining and describing it. The specimens were dredged on the 22nd July, 18;2, lat. $14^{\circ} 8^{\prime \prime}$ N., long. $77^{\circ} 38^{\prime \prime}$ W., 800 to 1000 fathoms; and Dr. Gassiot in his letter to me states, "Reliance can be placed on statement of locality, depth \&c., as the specimens were put into bottles and marked by Capt. Hunter, who is a most energetic officer and careful observer.

FarRea pocillum, Bowerbank.

Sponge cup-shaped, contracted; pedicel short; parietes thin. Oscula, pores, and dermal membrane unknown. Skeleton siliceofibrous ; fibres cylindrical, furnished more or less with short acutely conical spines; rete more or less rectangulated, rather irregular; central canal very slender, often terminating abruptly in a cæcoid manner. Internal defensive organs rectangulated sexradiate, rather large, based on the sides of the fibres; radii attenuated, abundantly spinous, and also furnished rather abundantly with rectangulated sexradiate spicula, small and slender; radii attenuating, incipiently spinous. Sarcode dark and opaque.

Colour, in the dried state, very faint rose-pink.

Hab. West-Indian seas (Capt. Hunter, R.N.).

Examined in the dried state.

Proc. Zool. Soc.-1875, No. XVIII. 
I am indebted to my late friend Mr. Henry Deane for two specimens of this interesting species ; neither of them exceeds 8 lines in height and 5 in greatest diameter. From their form and other external characters they might readily have been mistaken for specimens of Farrea gassioti; but a microscopical examination readily separates them from that species. As was the case with $F$. gassioti, the characters derivable from the dermis, oscula, and pores were not available; so that the discrimination of the species was in a great measure dependent on the structural peculiarities of the skeleton ; and the resemblance of the two species in size, form, and mode of arrangement of the spicula is very close; but they differ very strikingly in the characters afforded by the central canals of the skeleton-structure. In those of P.gassioti, when examined beneath the microscope in Canada balsam with a power of 108 linear, they are strikingly large and distinct, while in $\boldsymbol{F}$. pocillum, although the fibres of the two species are as nearly as possible of the same size, they are remarkably slender, and in some cases nearly obsolete; and this was the case in portions taken from both of the specimens in my possession. These distinctive characters are quite sufficient to separate the two species; but there are fortunately others that aid materially in their discrimination. Thus in $\boldsymbol{F}$. pocillum there are numerous internal defensive organs of a rectangular sexradiate form, based on the sides of the skeleton, and projected into the areas of the rete. These organs are comparatively large and strong; and are abundantly furnished with large conical spines. Sometimes the primary central portion of these organs is destitute of the four lateral radii ; and occasionally the lateral radii are doubled in number, a second set of them being projected beyond the first ones. In addition to these internal defensive organs there are numerous unattached rectangular sexradiate spicula, occasionally grouped together in considerable numbers on the areas of the skeleton-rete. These spicula are very distinct from those organs of the same form which are based upon the skeleton-fibre ; they are very much smaller, and their radii are slender and usually spineless. All are alike acutely terminated, and have evidently never been based upon the skeletonfibres, as the organs first described always are. The presence of these organs in the one species and their apparent complete absence in the other strongly confirms the propriety of their separation, notwithstanding the close resemblance they bear to each other in external form.

The specimens were dredged July 22,1872 , in lat. $14^{\circ} 8^{\prime} \mathrm{N}$., long. $77^{\circ} 38^{\prime}$ W., 800 to 1000 fathoms, by Capt. Hunter, R.N.

\section{Deanea, Bowerbank.}

Skeleton siliceo-fibrous. Fibres canaliculated; canals continuous. Rete symmetrical ; areas rotulate, confluent.

This genus is intermediate between Iphiteon of Valenciennes and Farrea. The skeleton has the confluent rotulate structure of the former, but differs from it in having the fibres distinctly canaliculated. It agrees with the latter genus in the canaliculation of the 
skeleton-fibre, but it differs essentially from it in the form of its reticular arrangement.

I have named the genus after my late friend Mr. Henry Deane, to whom I am indebted for my knowledge of the sponge.

Deanea virgultosa, Bowerbank.

Sponge sessile (?), virgultose, solid, irregularly cylindrical. Surface even. Oscula, pores, and dermis unknown. Skeleton symmetrical ; fibre cylindrical; central canals large and very distinct.

Colour, in the dried state, amber-brown.

$H a b$. West-Indian seas?

Examined in the skeleton condition.

All that remains of this interesting sponge is unfortunately its well-washed skeleton, so that little more can be said of it than what apertains to its generic characters; but these are fortunately very distinctive. The specimen is $\mathrm{J} \frac{1}{4}$ inch long, and of an average diameter of about 2 lines. Which has been its basal end cannot be determined, as both are broken terminations. The substance of the sponge is very compact, there being no central cavity. There are no indications on its surface of oscules, and not the slightest remains of either dermal membrane or sarcode.

When a section of the sponge is made at right angles to its long axis, mounted in Canada balsam and viewed with a power of 100 linear, its structure is beautifully displayed. Its singular confluent rotulate rete is as regular as that of Iphiteon, described and figured in the 'Proceedings' of this Society for May 1869, p. 323, pl. xxi. figs. 1 \& 2. No other form of structure occurs in the skeleton; and whether we view a transverse section, a longitudinal one, or the surface of the sponge, the same rotulate structure is presented to the eye.

The canaliculated structure is very strongly produced. The canals radiate from the axis of each rotulum, and usually appear to be continuous through the whole of the skeleton-structure; occasionally, but not frequently, a single ray will be entirely destitute of the central canal; but this is the exception, not the rule. The skeletonfibres vary in diameter from $\frac{1}{666}$ inch to $\frac{1}{333}$; but the general average is about $\frac{1}{350}$ inch. The central canals are large in proportion to the size of the fibres; their range in diameter is from ${ }_{10}^{1} 00$ inch to $\frac{1}{3333}$ inch, but their average diameter is about $\frac{1}{1500}$ inch. They are not always in proportion to the size of the fibre, the largest canals being frequently in the smallest fibres.

Since the above description was written $I$ have received a small fragment of another specimen of the sponge. It is a piece of a similar small cylindrical mass, about 3 lines in length and rather less in its diameter. In this specimen there are remains of sarcode thinly coating some of the skeleton-fibres; and in many of them the canals are lined with a sarcodous membrane of a dark amber-brown colour, a strong evidence that the sponge was in a living state when taken. No spicula of any description could be detected in any part of the 
specimen. The confluent rotulate form of skeleton-structure is not confined to the siliceo-fibrous sponges; it also occurs in the dermis of a rare British sponge, Desmacidon rotalis. In this case it does not occur in the internal skeleton of the sponge, but in the reticulated dermis only. I have figured this beautiful dermal tissue in vol. iii. pl. xc. fig. 9, 'Monograph of the British Spongiadæ.'

The specimen of Deanea virgultosa figured was presented to me by my late friend Mr. H. Deane, along with those of Farrea gassioti and pocillum; and I presume it is from the same locality as those species.

Farrea fistulata, Bowerbank.

Sponge fistulous, orifices both terminal and lateral, very large, parietes thin. Surfaces, exterior and interior, even, but rough to the touch, each abundantly armed with a single series of harrow-like teeth, based on the angles of the skeleton-tissues, and projected outwardly from their respective surfaces. Oscula and pores unknown. Dermal membrane thin, abundantly spiculous; tensionspicula acerate, variable in size, rather numerous; retentive spicula simple and contort, bihamate, numerous, dispersed. Skeleton-fibre cylindrical, smooth and even; canals large and very distinct; rete symmetrically quadrangular, areas usually square. Internal defensive spicula attenuato-acuate, basally spined, based on the skeleton-fibres, projected at about right angles into the areas of the rete. Sarcode dark amber-colour, thinly coating the skeleton-structures.

Colour, dried state, dark amber-brown.

$H a b$. West-Indian seas?

Examined in the dried state.

This remarkable sponge consists of a single thin stratum of skeleton-tissue in the form of a compound pipe about four lines in diameter. It has all the appearance of being only a portion of a more perfect specimen. It is but an inch in length, but in that short space it has six open terminations of what has apparently been as many ramifications of its fistulous structure; and none of these orifices have a natural or an even margin. The general surface of the specimen is even, and no indications are apparent of either oscula or pores. The dermal membrane is in an excellent state of preservation on the surface of the sponge; and from its present condition it was evidently in a living state when taken. It is a thin translucent structure, abundantly spiculous. The tension-spicula are slender and acerate, not very numerous ; they are variable in size and irregularly disposed on the surface of the membrane. The bihamate retentive spicula are rather numerously dispersed on the membrane; they are slender and very equable in size. The skeleton is a remarkably beautiful structure. The fibre is perfectly smooth, very equable in its diameter, and it is arranged as nearly as possible in a regular quadrangular network. The central canals are moderately large and very distinct, and are as equable in their diameter and mode of distribution as the rete of the skeleton is. The thin stratum of 
skeleton-structure appears to consist of two and sometimes three layers of this beautiful network. The outer and the inner layers are powerfully armed by a single series of stout harrow-like teeth projected from the angles of the network at right angles to the surface; and each of these teeth is furnished with numerous imbricated scales, like the similar organs in Farrea occa, described in the 'Proceedings of the Zoological Society of London,' for May 13, 1869, p. 339. These organs in the species under consideration differ from those in $\boldsymbol{F}$. occa in being longer and more slender in their proportions. If the specimen be examined by direct light with a power of 50 linear, these structures are exhibited in a very beautiful manner, projecting outwardly from the angles of the dermal layer of the quadrangular network at right angles to its surface, and from the internal skeleton. layer in like manner into the interior cavity of the sponge, while the intermediate layer or layers of the skeleton are entirely destitute of these organs; but in place of them they are abundantly furnished with attenuato-acuate entirely spined internal defensive spicula, which are based on the sides of the skeleton-fibres, and are projected at various angles into the areas of the rete. These internal defensive spicula are very numerous where the fibre is well coated with the dark amber-coloured sarcode; but when the sarcode is absent not a single spiculum is to be seen on the fibres. The skeletonfibres of the interior surface do not appear to be furnished with internal defensive spicula; but those of the outer and intermediate layers are abundantly furnished with them. These spicula vary to a considerable extent in size, the longer being frequently twice the length of the shorter ones. The basal half of both is abundantly spinous, while the distal half is usually entirely spineless. The spines are short and acutely conical. I could not detect any interstitial membranes; but a few large acerate spicula were observed in the interstitial spaces; but whether they belonged to the sponge or were adventitious I could not determine, as several other forms of spicula were observed on both the outer and the inner surfaces of the sponge. On examining the interior of the sponge with a lens of two inches focus through one of the large terminal orifices I observed a small patch of flocculent-looking sponge-tissue; and on removing a portion of this and mounting it in Canada balsam, it proved to be a very young Hymedesmia johnsonia in an excellent state of preservation, with numerous specimens of that remarkable form of spiculum, the trenchant contort bihamate, dispersed among the acerate skeletonspicula of that sponge, and closely resembling the portion of the type specimen represented in vol. i. plate xviii. fig. 293, 'Monograph of British Spongiadæ.' The occurrence of this well characterized sponge parasitical within the Farrea is a remarkable circumstance, and it seems to indicate that the open tubular structure of that sponge is probably its normal condition. Beside Hymedesmia johnsonia, naturally parasitical on its inner surface, there were two other small groups of sponge-spicula that were evidently adventitious. One consisted of numerous short entirely spined cylindrical spicula distributed irregularly over the fibres of three or four areas of the skele- 
ton of the Farrea. The other groups consisted of two small densely compacted masses of very minute cylindro-stellate spicula with acutely conical radii : one of these groups just filled a skeleton-area ; the other, of a similar size, was not entangled in the skeleton-structure, but adherent to it externally; and within the little mass were a few spiculated biternate spicula, like those found in Farrea occa, figured in vol. i. plate ix. fig. 199, 'Monograph of British Spongiadæ.' A few minute anchorate spicula of different forms were also observed among the skeleton-fibres. These occurrences would seem to indicate that the locality whence this sponge was obtained would be a very prolific ground for scientific dredging. I received this sponge from my late friend Mr. H. Deane, with the specimens of Farrea gassioti and pocillum; and I therefore presume it is from a West-Indian locality.

\section{FARrea Lavis, Bowerbank.}

Sponge-mass unknown. Dermis furnished with a quadrilateral siliceo-fibrous network. Rete armed at the angles oppositely externally and internally with smooth elongate-conical attenuated spicular defences. Fibre smooth and spineless ; central canals large and very distinct, confluent at the angles, frequently two, rarely three, in each fibre. Dermal membrame thin, aspiculous. Sarcode amberbrown.

Colour, in the dried state, brown?

$H a b$. West-Indian seas?

Examined in the dried state.

I am indebted to my friend Mr. Henry Lee for my knowledge of this species. He found it on some sand dredged up by Mr. Marshall Hall during his voyage in the 'Norna.' The sand was preserved by Mr. W. Saville Kent, and was presented by him to my friend. Mr. Lee sent me the specimen for examination. It is a fragment of a very fragile tubular sponge, which consists of only one layer of siliceo-fibrous tissue. It is five lines in length, and does not exceed three lines in diameter. The form of the fibres and their mode of arrangement very closely resemble those of the dermal tissue of Farrea occa; but they differ from those of that species in being smooth and quite destitute of spines, and also in being furnished abundantly with central canals. The conical spicular external defences at the angles of the rete differ also from those of $\boldsymbol{F}$. occa, as, instead of being imbricated as in that species, they are quite smooth and each is furnished with a well-developed central canal. The canals in the fibres of the rete form a very prominent feature in this sponge; they are large and well developed, and are confluent at the angles of the network. There are frequently two in each fibre, one appearing to emanate at each end; when they meet they do not unite, but rum parallel to each other to their opposite angles.

The dermal membrane is preserved in a few of the areas of the network. It is thin and transparent, and is well coated with sarcode, but I could not detect a single spiculum in any part of it. The 
smoothness of the skeleton and the well-developed system of canals in the fibres at once distinguish this species from either $\boldsymbol{F}$. occa or $\boldsymbol{F}$. spinulenta. It is remarkable that the sponge appears to consist of a single layer only, as I could not find the slightest trace of any other siliceo-fibrous structure on any part of the specimen.

Mr. W. Saville Kent has evidently mistaken this species for Farrea occa in the description he gives of that species in the 'Microscopical Journal' for Nov. 1870, p. 248, plate lxiv. figs. 12-18; and he has correctly figured the central canals in the dermal network of his specimen (fig. 13), whereas in the corresponding organs of Farrea occa no such canals are visible. The description of the sponge represented in the same plate by fig. 12 is quite in accordance with the small fragment of the species $F$. laevis that $\mathrm{I}$ received from Mr. Lee. Mr. Kent writes, "The skeleton of this sponge is composed of a series of infundibular netted tubuli branching out from one another and occasionally coalescing." The branching fistular form represented by $\mathrm{Mr}$. Kent in fig. 12, plate lxiv. 'Microscopical Journal' for Nov. 1870, occurs also in $\boldsymbol{F}$. tubulata, very much in the shape represented by Mr. Kent; but the other specific characters differ to a very considerable extent from those of $\boldsymbol{F}$. lavis. I received this sponge from my late friend $\mathbf{M r}$. $\mathbf{H}$. Deane, along with the specimens of Farrea gassioti and pocillum; and I presume it is from the same locality as those species.

\section{Farrea parasitica.}

Sponge parasitic, coating. Surface irregular? Oscula, pores, and dermal membrane unknown. Skeleton-rete irregular; fibres depressed, occasionally confluent, very irregular in breadth; canals distinct, variable in diameter, not always confluent, but usually so.

Colour translucent as glass.

Hab. West Indies (Captain Hunter, R.N.).

Examined in the skeleton state.

During the course of my examination of the beautiful little specimen of Farrea gassioti, I observed on the inner surface of the sponge several small thin patches of siliceo-fibrous tissue, very much finer in structure than the skeleton of the sponge to which they were attached. On removing small portions of these tissues and mounting them in Canada balsam I found them to be strikingly different in all their specific characters from the sponge on which they reposed, and especially so in the size of their skeleton-fibres-the average diameter of those of $F$.gassioti being $\frac{1}{2} \frac{1}{86}$ inch, while those of $\boldsymbol{F}$.parasitica was $\frac{1}{1308}$ inch ; and the canals in the former species averaged $\frac{1}{1490}$ inch in diameter, while in the latter one their average was $\frac{1}{9375}$ inch. These discrepancies, if there were none other, distinctly separate them as species, although in such close contact in their natural condition. I could not, with a power of 100 linear, detect any indications of a natural dermal surface, nor could I by any means find portions of dermal or interstitial membranes or of sarcode ; our sole dependence, therefore, is upon the structural pecu- 
liarities of the skeleton; and in these fortunately there are very sufficient distinctive characters to assist us in the description of the species. In some of the little patches of this parasitical sponge there are several layers of the skeleton-structure, while in other cases it spreads like a single network over the surface of the sponge upon which it is parasitical.

There is no definite arrangement in the skeleton-rete, and the areas assume a great variety of forms. The skeleton-fibre is always more or less depressed ; and in some cases two or more fibres coalesce, forming small broad plates of siliceous structure in which two or three canals may be seen running in parallel lines. The fibres in their normal condition vary to a considerable extent in their diameter : the largest measured was $\frac{1}{42}$ inch, whilst the smallest was $\frac{\pi}{3000}$ inch in diameter; the average diameter of four measured was $\frac{1}{1380}$ inch. The central canals of the fibres also vary in their diameter; the largest was $\frac{1}{3750}$ inch, and the smallest $\frac{1}{5000}$ inch in diameter. Their course through the fibres is not always continuous; and frequent cases occur in which they terıninate abruptly before reaching the angle of the network towards which they are progressing.

The specimen described is the only one $I$ have yet seen; but it is probable that it will be found parasitical on other species of siliceofibrous sponges beside Farrea gassioti.

The locality is the same as that of $F$. gassioti, lat. $14^{\circ} 8^{\prime} \mathrm{N}$., long. $77^{\circ} 38^{\prime} \mathrm{W}$., in 800 to 1000 fathoms.

\section{EXPLANATION OF THE PLATES.}

\section{Plate XXXIX.}

Fig. I. Farrea gassioti, natural size.

2. A small portion of the outer surface of the skeleton of $F$. gassioti from the distal margin of the specimen represented by fig. $1, \times 36$ linear.

3. A small portion of the piece of the skeleton represented by fig. 2 , exhibiting the mode of the canaliculation of the fibre of the skeleton, $\times 80$ linear.

4 \& 5. Two specimens of Farrea pocillum, natural size.

6. A portion of the skeleton of $F$. pocillum from the specimen represented by fig. 5, exhibiting the more or less irregular mode of its reticulation, $\times 36$ linear.

7. A small piece of the skeleton of the specimen represented by fig. 4 , exhibiting the spination of the skeleton-fibres and the numerous rectangulated sexradiate defensive organs in situ, $\times 80$ linear.

8. One of the rectangulated sexradiate defensive organs, exhibiting the mode of its spination, $\times 150$ linear.

\section{Plate XL.}

Fig. I represents a specimen of Deanea virgultosa, natural size.

2. A portion of the skeleton of the specimen represented by fig. 1, exhibiting the rotulate mode of arrangement of the skeleton-rete and the large central canals within the fibre, $\times 36$ linear.

3. Farrea fistulata, natural size.

4. A small piece of the skeleton of the specimen represented by fig. 3 , exhibiting the quadrangular form of the rete and their large central canals, $\times 36$ linear.

5. A portion of a specimen of Farrea lavis, natural size.

6. A fragment of the specimen represented by fig. 5 , exhibiting the form of 
the dermal rete with its central canals, and the smooth elongate-conieal defensive organs, $\times 36$ linear.

Fig. 7. A small portion of the siliceo-fibrous skeleton of Farrea parasitica, $\times 80$ linear.

2. Contributions to a General History of the Spongiada. By J. S. Bowerbank, LL.D., F.R.S., \&c.-Part VII.

[Received March 12, 1875.]

When my friend Commodore Parish went out to China to take the command at Hong Kong, he kindly promised to render me any assistance in his power in the collection of Sponges and other specimens of natural history; and I am pleased to say he has performed his promise in a most effective and liberal manner. By far the greater number of specimens of Sponges sent home to England are so carefully and effectually washed instead of being dried immediately in the condition in which they come from the sea, that the greater portion of their most valuable specific characters are completely destroyed. This destructive process has been carefully avoided in the preservation of the specimens which form the subjects of the present communication ; and the descriptions of these specimens are the more valuable to science as they lead us to the conclusion that the species at that distant portion of the earth are in reality very closely allied in their generic and other anatomical characters to those of our Northern European seas.

Microciona tuberosa, Bowerbank.

Sponge massive, sessile, tuberous; tuberous projections corrugated, minutely spinous, more or less fistulous. Oscula simple, small, dispersed. Pores inconspicuous. Dermal membrane pellucid, spiculous; tension-spicula acuate, slender, dispersed, rather few in number. Skeleton-columns rather stout, anastomosing, forming a coarse, open, and somewhat complicated rete; skeleton-spicula acuate, rather long and slender; internal defensive spicula attenuato-acuate, small, entirely spinous. Interstitial membranes spiculous; tensionspicula slender, acuate, few in number.

Colour, in the dried state, dull pale green.

Hab. Straits of Malacca (Commodore Parish, R.N.).

Examined in the dried state.

This very remarkable sponge was sent to me by my friend Commodore Parish with several other interesting and valuable specimens collected in the Straits of Malacca. It is based on the surface of another species of sponge, a unispiculous Halichondria, which it almost entirely covers, and with which it is so intimately incorporated, and so closely resembles it in colour, as to render it very difficult to discriminate the two without a microscopical examination of their structures. Its external form is singular and very characteristic. It is $2 \frac{1}{2}$ inches long, $1 \frac{1}{2}$ broad, $1 \frac{1}{4}$ inch in height; and its external 
surface is entirely composed of tuberous projections, the surfaces of which are minutely corrugated. They vary from a $\frac{1}{4}$ to $\frac{1}{2}$ an inch in height, and in diameter from 2 to 4 or 5 lines. Their distal terminations are slightly convex or nearly flat, with a simple orifice frequently on the summit, and when in this condition they are more or less fistulous. The oscula are simple perforations, seldom exceeding the size of one of the skeleton-areas. The dermal membrane is pellucid. It is rather sparingly furnished with slender acuate tensionspicula, which are of the same form as those of the skeleton columns, but rather shorter and more slender; and intermixed with the tension-spicula there are numerous minute grains of sand and other extraneous matters adherent to the outer surface of the membrane.

The skeleton in this species is more complicated in its structure than it is in the greater number of the known species of the genus, the skeleton-columns anastomosing more frequently and more regularly than is usual; so that the skeleton assumes the form of a rudely constructed reticulation. The skeleton-columns are stout and strong, abounding in keratode, in which their long, slender, acuate spicula are somewhat loosely distributed; and along with them there are frequently minute grains of extraneous matter imbedded. The columns are abundantly supplied with internal defensive, attenuatoacuate, entirely spined spicula; they are projected at nearly equal distances and at right angles to the surface into the interstitial spaces, so as to present an exceedingly formidable series of weapons of defence against the attacks of any intrusive annelids or other enemies. 'These defensive spicula require a linear power of about 300 to render their forms and spination distinctly to the eye.

The interstitial membranes are furnished with a few tension-spicula and extraneous grains of sand in a manner very similar to that of the dermal membrane. The spicula of this species have their nearest alliance in form to those of our British species M. fallax; but the structural characters of the sponge in other respects are very strikingly different.

In the spicula prepared by boiling in nitric acid and mounting in Canada balsam there were numerous adventitious forms of spicula, which the peculiarities of the structure of this sponge is especially liable to collect and retain; but of these very few, comparatively, could be detected on the insterstitial membranes of the sponge.

\section{Hymeraphia Spinularia, Bowerbank.}

Sponge coating, very thin. Surface even, strongly hispid. Oscula simple, minute, dispersed. Pores inconspicuous. Dermal membrane pellucid, sparingly spiculous ; spicula same as those of the skeleton. Skeleton and external defensive spicula subfusiformi-spinulate, long and rather slender, very numerous. Internal defensive spicula subfusiformi-spinulate, comparatively short and stout, numerous.

Colour, in the dried state, light ochreous yellow.

Hab. Coast of Corea (Commodore Parish, R.N.).

Examined in the dried state. 
This sponge is parasitical on the shell of a large specimen of Spondylus spathuliferus (?), which measures from the hinge to the front of the shell nearly 3 inches. It completely covers every part of the shell and all its spines, many of which exceed 1 inch in length ; and in no part does it appear to exceed in thickness a stout sheet of paper. The surface is abundantly but minutely hispid by the projection of the skeleton-spicula through the dermal membrane for about half their entire length, thus performing the offices of external defensive spicula as well as those of the skeleton. The oscula are simple orifices, so minute as not to be readily detected even with the aid of a lens of 2 inches focus. In the specimen under description there are appearances very liable to deceive an observer in search of these organs, as they assume a form very likely to deceive the eye, that of little conical elevations terminating in small circular orifices.

These fallacious appearances are thus produced. Before the shell was covered by the sponge a considerable number of small Balani had built upon its upper valve and also upon some of the spines; and these shell-parasites have become so completely covered by the sponge as to leave only the terminal orifice of each visible, simulating in a remarkable manner what might readily be mistaken for the oscula of the sponge. The dermal membrane is pellucid; it is situated about midway between the bases of the skeleton-spicula and their apices; and a few spicula of the same size and form as those of the skeleton are distributed on its surface. The skeletonspicula all spring from the basal membrane of the sponge, and are projected through the dermal one for about half their lengths: they vary to some extent in length; a fully developed one measured $\frac{1}{48}$ inch in length; and as they pass for about half their length through the substance of the sponge, its entire thickness will be about $\frac{1}{100}$ inch. The skeleton-spicula are all more or less fusiform, and in many of them the spinulate base is very slightly produced; their greatest diameter is $\frac{1}{2308}$ inch.

The internal defensive spicula all spring from the basal membrane : their average length is $\frac{1}{214}$ inch; and their diameter is rather less than that of the skeleton-spicula; some of the largest of them reach very nearly to the inner surface of the dermal membrane.

This species is closely allied to the British Hymeraphia simplex; but it differs from it in having the skeleton-spicula much more slender and delicate, and in their fusiform shape, and also by the total absence of attenuato-spinulate incipiently spinous defensive spicula.

\section{RAPHIOdESMa PARISHII, Bowerbank.}

Sponge sessile, coating thinly, even, minutely hispid; spicula acuate, same as those of the skeleton, visibly reticulated. Oscula simple, dispersed, small, rather few in number. Pores inconspicuous. Dermal membrane abundantly spiculous, reticulated; rete multispiculous, strongly developed; areas rather irregular in form, but nearly equal in size; spicula of rete acuate, same size and form as those of the skeleton; tension-spicula biclavate cylindrical, very slender, dispersed or loosely fasciculated, and tricurvate acerate, small and 
very slender. Retentive spicula inequidentato-palmate anchorate, congregated in circular groups or dispersed, large and strong; and very minute palmato-inequianchorate, dispersed; also very minute, bidentate, equianchorate, dispersed; and also bidentate, equianchorate, rather large and stout, few in number; also bihamate simple and contort large and strong, and the same form very minute and slender. Skeleton-fasciculi more or less multispiculous; bases and apices of the component spicula coincident, irregularly disposed; spicula acuate, stout, moderately long; basal membrane stout, somewhat coriaceous, abundantly armed with attenuato-acuate entirely spined internal defensive spicula; interstitial membranes spiculous ; spicula same as those of the dermal membrane, rather sparingly dispersed.

Colour dull cream-white in the dried state.

Hab. Straits of Malacca (Commodore Parish, R.N.).

Examined in the dried state.

I received six specimens of this very interesting sponge from my friend Commodore Parish, who obtained them from the Straits of Malacca. The largest measured $3 \frac{1}{4}$ inches in length by $1 \frac{3}{4}$ broad, and its greatest thickness does not exceed about $\frac{1}{8}$ of an inch. It entirely covers a mass of Cellepora about a $\frac{1}{4}$ of an inch in thickness. The surface appears smooth to the eye, but it is really minutely hispid. The hispidation is produced by the projection of about half the length of the spicula of skeleton-fasciculi; the distal ends of each of them separate divergingly, forming an infinite number of minute external defensive groups ; as the amount of their projection does not exceed $\frac{1}{160}$ inch, this character is only to be ob. served in sections at right angles to the surface mounted in Canada balsam. This radiating expansion of the skeleton-fasciculi at the surface of the sponge, so as to form an efficient system of external defence, is on the same principle as the expansion of the distal terminations of the primary fibres of the skeleton of many species of the genus Isodictya, thus exhibiting in a very different mode of the construction of the skeleton the same economic design in the production of a series of organs of external defence. In other genera where this beautiful mode of adaptation is inapplicable, especial systems of spicula are provided to achieve the necessary defences of the dermal surface.

The dermal membrane and the interstitial tissues are remarkably rich in defensive and retentive spicula; and $I$ have never found in any other sponge so great a number of forms and so much variety of size as in this species. The dermal rete is very strongly and compactly constructed; but the spicula composing it have not their terminations coincident as in the skeleton-fasciculi. Both forms of tension-spicula are small and slender. The biclavate cylindrical ones are $\frac{1}{150}$ inch in length and $\frac{1}{10000}$ inch in diameter; the greater number of them are collected into fasciculi containing from five to eight or nine spicula; and others are singly disposed among the rest of the spicula. The fasciculi have no especial mode of distribution. 
The tricurvate acerate tension-spicula are also very small and slender ; one of the largest of them measured $\frac{1}{300}$ inch in length : the curves of these spicula are not very strongly produced, and some of them exhibit but faint traces of curvature ; they are not very numerous. The retentive spicula are especially remarkable for the great variety of their size and form. The largest of the retentive spicula, the inequidentato-palmate anchorate ones, are congregated in rosetteshaped groups, a few only appearing singly located. The groups of these spicula so characteristic of the genus Raphiodesma are not very numerous, nor do they contain so many spicula as those we observe in some other species of the genus; the usual number is about eight or ten in each. They are situated on the basal membrane as well as on the inner surface of the dermal one, just as similar groups of such spicula are dispersed on the inner surface of our British species $R$. lingua, in which they are frequently crowded together in considerable numbers. The spicula in the species in course of description are strongly produced; an average-sized one measured $\frac{1}{4} 61$ inch in length, and the breadth of the broad spatulate distal end was $\frac{1}{1000}$ inch. These dimensions contrast strongly with those of the numerous small inequipalmate anchorate ones dispersed on the surface of the membranes, the average length of which is $\frac{1}{1428}$ inch; and the contrast is still greater with the very minute palmatoequianchorate ones, two of which measured respectively $\frac{1}{2308}$ and $\frac{1}{3000}$ inch in length; so that a considerable number of the latter ones might be shovelled up as in a scoop by one of the large form of these spicula which compose the large rosette-like groups. One of the stout bidentate equianchorate spicula measured $\frac{1}{666}$ inch in length. A similar difference in size occurs between the two sorts of bihamate spicula. The larger of the two measured $\frac{1}{30} 0$ inch in length, with greatest diameter of the shaft $\frac{1}{3614}$ inch, while the length of one of the smaller description of this form was $\frac{1}{1500}$ inch.

The fasciculation of the skeleton is very variable; some of the bundles contain numerous spicula, while others consist of two or three only ; and the mode of disposition of the fasciculi is also very irregular. The spicula in all the bundles appear to have their bases and apices coincident. The length of an average-sized skeletonspiculum is $\frac{1}{80}$ inch, and the diameter $\frac{1}{2307}$ inch.

The basal membrane is abundantly armed with numerous attenuatoacuate entirely spined internal defensive spicula projected at right angles to its inner surface. In the basal portion of the sponge a thin stem of a Tubularia was imbedded; and this was closely surrounded by basal membrane, from all parts of which numerous internal defensive spicula were projected. This curious habit of the sponge to surround included extraneous matters with membrane, and then to project defensive spicula from their surfaces, I have several times observed in some of our British sponges.

On the surface of another sponge from the same locality I found a very young specimen of the sponge under description not exceeding a $\frac{1}{4}$ of an inch in diameter and as thin as a piece of paper. The dermal membrane was in a fully developed condition; the basal 
membrane was present as a very thin film; and the skeleton was indicated by a few straggling spicula only; so that in this state the specimen might have been readily mistaken for a Hymedesmia.

I have named this remarkably interesting species after my good friend Commodore Parish, to whom I am indebted for it and many other interesting sponges, and also for numerous other interesting and valuable specimens of natural history.

\section{HalichondRia elegantia, Bowerbank.}

Sponge massive, sessile. Surface variable but smooth, or but slightly rugose. Oscula simple, dispersed. Pores inconspicuous. Dermal membrane pellucid, in parts slightly coriaceous, furnished with a rather irregular unispiculous network of short acerate spicula, of the same form and size as those of the skeleton, and also with numerous simple and contort bihamate retentive spicula. Skeletonrete rarely more than unispiculous, somewhat irregular; spicula acerate, rather short and stout. Interstitial membranes furnished rather abundantly with very minute simple and contort retentive spicula.

Colour, in the dried state, pallid green.

Hab. Straits of Malacca (Commodore Parish, R.N.).

Examined in the dried state.

I received this interesting and elegantly constructed species of Halichondria from my friend Commodore Parish, who obtained it from the Straits of Malacca. The sponge is, in a great measure, covered by the specimen of Microciona tuberosa described in this paper. Its length is about $2 \frac{1}{2}$ inches, and its breadth about $1 \frac{1}{4}$ inch. The dermal membrane is smooth and pellucid, and it is furnished with a beautiful unispiculous rete, the areas of which are somewhat unsymmetrical. The reticulated structure of the skeleton accords very closely with that of the dermis : it is mostly unispiculous, but occasionally it is bi- or trispiculous, and is characterized by the same irregularities in the reticulation that exist in the dermal structure, so that the whole structure is light and elegant. The form and size of the spicula are the same in all parts of the sponge; they are rather short and stout. The retentive spicula of the dermal and interstitial membranes are especially characteristic of the species; they are rather abundantly distributed on some parts of those tissues and but sparingly so on others, and they are so minute as to require a power of about 400 linear to render them distinctly to the eye.

The nearest allied species to this sponge is our British Halichondria couchii. In size and external form they are very different from each other; but structurally, as regards the dermal and skeletontissues, they so closely resemble each other as to render it very difficult to separate them. Fortunately the abundance of bihamate retentive spicula in $H$. elegantia and their complete absence in $H$. couchii renders the discrimination of the two species easy and certain. 
Halichondria aspera, Bowerbank.

Sponge massive, sessile; surface uneven and very rugged. Oscula simple, large and numerous, dispersed. Dermal membrane pellucid, abundantly spiculous; tension-spicula biclavate cylindrical, loosely fasciculated; and long and slender acerate,. dispersed; retentive spicula bidentate equianchorate, stout and comparatively large, few in number; and the same form very minute and rather numerous; also bihamate, comparatively large and strong, few in number; and the same form very minute and slender and much more numerous. Skeleton-rete more or less multispiculous, rather regular; spicula short and stout, acuate, occasionally subflecto-acuate. Interstitial membranes sparingly furnished with the same tension- and retentive spicula as the dermal membrane.

Colour, in the dried state, pallid green.

$H a b$. Straits of Malacca (Commodore Parish).

Examined in the dried state.

I received this sponge among others from my friend Commodore Parish, who obtained it from the Straits of Malacca. It is $2 \frac{1}{2}$ inches long by 2 in breadth; and the thickness is rather more than an inch. Its form is very irregular, and its surface exceedingly rugged and uneven, abounding in minute ridges and asperities, so much so that it is difficult at the first sight to distinguish the oscula. The dermal membrane is abundantly furnished with spicula. There are two distinct forms of the tension ones; the most abundant of the two are the biclavated cylindrical ones, which are usually gathered together in loosely formed fasciculi of from two or three to six or eight; and a few of them are dispersed singly among the others. The fasciculi are disposed without any approximation to order. The second form of tension-spiculum is very slender acerate or fusiformi-acerate; they are longer than the biclavated cylindrical ones, but less in their greatest diameter, and they are distributed singly in considerable number among the others. The occurrence of two distinct forms of tension-spicula and two different modes of their distribution is very rarely seen in the dermal membrane of the same sponge, and thus it is very characteristic of the species. The retentive spicula are also very remarkable in this species. There are two distinct sorts of bidentate equianchorate ones, and also of bihamate spicula. The largest sort of bidentate equianchorate ones are more than twice the size of the smaller anchorate ones; comparatively they are stout and strong; but they are very few in number, while the smaller ones are comparatively numerous. A full-sized large one measured $\frac{1}{1000}$ inch in length, while the average length of smaller ones was $\frac{100}{2300}$ inch in length. The same difference in size exists between the two sorts of bihamate spicula. The largest sort measured $\frac{1}{750}$ inch in length, while two of the smaller ones measured respectively $\frac{1}{1500}$ and $\frac{1}{187.5}$ inch in length. They are also comparatively very numerous, while the larger ones are of very rare occurrence. No gradational sizes exist between the large and small forms of either the anchorate or bihamate spicula. The small 
description of both of these organs require the application of a power of at least 400 linear to render them distinctly to the eye. Their minuteness is such that they do not exceed in length the diameter of a skeleton-spiculum, $\frac{1}{1500}$ inch.

The skeleton-rete is strongly developed, and the spicula are comparatively short and very stout.

The nearest alliance to this sponge among our British species is Halichondria forcipis. Its general habit, the forms and modes of disposition of the spicula of the dermis, and the form and proportions of the skeleton-spicula exhibit close resemblances; but in other important characters the two species are essentially different.

\section{HaLichondria Frondifera, Bowerbank.}

Sponge branching from the base numerously; branches rather compressed, frequently dividing, distal terminations spinoid. Surface minutely rugose. Oscula simple, minute, dispersed. Pores inconspicuous. Dermal membrane abundantly spiculous; tensionspicula acuate, rather long and slender, dispersed; retentive spicula bidentate equianchorate, very minute and few in number. Skeletonrete multispiculous, compact, rather close and strong, areas small; spicula acuate, rather stout and short. Internal defensive spicula attenuato-acuate, entirely spined, short and stout, uniform in size, rather numerous.

Colour, in the dried state, dull grey.

$H a b$. Straits of Malacca and Gaspar Straits (Commodore Parish, R.N.).

Examined in the dried state.

I am indebted to my friend Commodore Parish for this remarkable sponge; he obtained it with many others from the Straits of Malacca. It is attached to the shell of a small Spondylus, nearly the whole of the valve of which is covered by the thin basal portion of the sponge, from which numerous slender compressed branches are given off, some of them nearly two inches in length; each of these branches resembles in form a stag's horn, but with many more divisions than would be possessed by the horn. The oscula are simple and minute, a few only near the distal terminations of the branches being visible with the aid of a lens of two inches focus. The tension-spicula of the dermal membrane are exceedingly numerous, so much so as almost to present a felted appearance ; they are quite as long as those of the skeleton, but not more than half their diameter. The bidentate equianchorate retentive spicula are very minute and slender, and very few in number: I could not detect them in situ; but amidst the spicula prepared by the action of nitric acid I found them on some of the fragments of the dermal membrane and a very few among the other spicula; one of the largest of them measured $\frac{1}{2000}$ inch in length. They require a power of about 400 linear to render them distinctly to the eye. The attennato-acuate, entirely spined, internal defensive spicula are uniform in size and rather numerous; they are based on the skeleton-rete, and 
are projected at right angles to the fibre into the areas, frequently in considerable numbers; a power of about 300 linear is required to exhibit them in situ in a satisfactory manner; their length rarely exceeds $\frac{1}{30} \sigma$ inch.

The acuate skeleton-spicula are distinctly different in their proportions from those of the dermis; their diameter is twice that of the dermal ones. A full-sized one measured $\frac{1}{2000}$ inch in diameter.

Since the above description was written I have examined another specimen of this species, sent to me from the Straits of Gaspar by Commodore Parish. It is, in its external and anatomical characters, very like the type one, but rather larger and more strongly developed. A remarkable circumstance attending this specimen is that it has two very interesting radiate animals seated upon it, the small or basal arms of which are so interwoven amidst the branches of the sponge as to render it impossible to disentangle them without the destruction of the radiate animals, while the larger and longer arms for entangling their prey are thrown out above in every direction. Their mode of anchoring themselves on the sponge is an interesting fact in their natural history.

\section{HaLichondria Rigida, Bowerbank.}

Sponge massive, sessile. Surface very rugged and uneven, full of ridges and depressions. Oscula simple, dispersed. Pores inconspicuous. Dermal membrane pellucid, spiculous; tension-spicula acuate, the same diameter and nearly the same length as those of the skeleton; retentive spicula bihamate, simple, and contort, rather numerous ; and bidentate equianchorate, small, but rather stout, not numerous. Skeleton-rete multispiculous, very wide and open, irregular; areas very variable in size; spicula purely acuate, rather short and stout. Interstitial membranes sparingly spiculous; spicula same as those of the dermis.

Colour, in the dried state, dull green.

Hab. Straits of Malacca (Commodore Parish, R.N.).

Examined in the dried state.

I obtained this sponge from my friend Commodore Parish. It is from the Straits of Malacca. It is $2 \frac{1}{2}$ inches long, 1 inch wide, and rather exceeds half an inch in average thickness.

The dermal membrane is rather sparingly furnished with tensionspicula. There is very little difference between these spicula and those of the skeleton; the latter are rather the longer of the two; their diameter is about the same. In consequence of the open structure of the skeleton-rete there are a considerable number of surreptitious spicula of various forms amidst the tissues of this sponge ; and fragments of some of these are occasionally incorporated in the skeleton-fibre, as in a Dysidea. The spicula in the fibre are numerous and closely compacted, and the areas very wide, but by no means equal or regular in either form or size. The bihamate retentive spicula are not very abundant; they are rather slender; and the simple and contort forms are about equal in number, and

Proc. Zool. Soc.-1875, No. XIX. 
they are about as numerous on the interstitial membranes as on the dermal one. The bidentate equianchorate ones are rather rare; they are not readily found in situ amidst the numerous minute grains of sand adherent to the membranes; but they are readily found among the spicula prepared by the aid of nitric acid, but they require the application of a power of about 400 linear to render them distinctly to the eye; they are stout and short in their proportions.

The interstitial membranes are usually rather sparingly spiculous; but occasionally the spicula are clustered together in considerable quantities.

\section{Halichondria crassa, Bowerbank.}

Sponge massive, sessile. Surface uneven and very rugged, with numerous irregular thin ridges and elevations, coarsely reticulated. Oscula simple, dispersed. Pores inconspicuous. Dermal membrane spiculous; tension-spicula acuate, same size and form as those of the skeleton, not very numerous ; retentive spicula, two descriptions of bihamate, simple and contort, large and small, and bidentate equianchorate minute, and few in number. Skeleton-rete multispiculous, coarse, and strong; areas large and irregular; spicula acuate, rather short and stout. Interstitial membranes spiculous; spicula same as those of the dermis.

Colour, in the dried state, dull pale green.

Hab. Straits of Malacca (Commodore Parish).

Examined in the dried state.

I received a single specimen of this sponge from my friend Commodore Parish, who obtained it from the Straits of Malacca. It is a rough-looking mass, very irregular in form, about $1 \frac{1}{2}$ inch in diameter, and half an inch in thickness, and it has several specimens of Balanus imbedded in its substance. Its surface is full of sharp, thin, elevated ridges and deep depressions; and all parts of its surface are coarsely reticulated, the reticulation being more or less visible to the unassisted eye, and very apparent by the aid of a lens of 2 inches focus. This coarse reticulation arises in the dried specimen from the very coarse and open character of the skeleton-structures immediately beneath the dermis.

The oscula are rather numerous; and some of them exceed a line in diameter. The dermal membrane is in some parts rather sparingly, and in others profusely, furnished with its respective spicula; the tension ones, like those of the skeleton, are purely acuate. Of the bibamate retentive spicula there are two distinct sizes-one comparatively large (that is to say, measuring on an average $\frac{1}{82}$ inch in length), while the minuter set of these forms measured only $\frac{1}{2727}$ inch in length. These minute forms could not be detected in situ; but in the remains of the membranes rendered transparent by the action of nitric acid and mounting in Canada balsam, and with a power of about 700 linear, they were distinctly visible. The bidentate equianchorate retentive spicula were also minute; they varied in length from $\frac{1}{1034}$ inch to $\frac{1}{75}$ inch, and required a power of about 400 
linear to define their forms distinctly; proportionately they were rather stoutly and strongly formed.

The structural peculiarities of the skeleton form a very striking specific character in this species. The rete is strongly and compactly formed, and the number of spicula in any part of it is far greater than can be counted. The areas are unsymmetrical and rather variable; and the interstitial membranes filling them are frequently abundantly supplied with the same description of spicula as those of the dermal one.

\section{Halichondria Compressa, Bowerbank.}

Sponge branching irregularly and abruptly; branches compressed. Surface more or less rugose or spinous. Oscula simple, dispersed. Pores inconspicuous. Dermal membrane spiculous; tension-spicula subclavate acuate, variable in form, dispersed or more or less fasciculated; retentive spicula bidentate, rarely tridentate equianchorate, comparatively large and very stout, rather few in number; and the same form minute and slender, numerous. Skeleton-rete multispiculous, very irregular; areas large and variable in form; spicula acuate, rather short and stout. Interstitial membranes sparingly spiculous; spicula same as those of the dermis.

Colour, in the dried state, dark green.

Hab. Straits of Malacca (Commodore Parish, R.N.).

Examined in the dried state.

I received this remarkable sponge with others from my friend Commodore Parish, who obtained it from the Straits of Malacca. It is rather less than 2 inches in height, and less than an inch wide at its greatest expansion. The external form is remarkably singular. It rises from a very small base, and immediately branches abruptly in every direction and at every possible angle. The branches are nearly all of the same size, and are all more or less compressed, and their surfaces rough and irregular.

The dermal membrane is comparatively stout, and in most parts it is abundantly spiculous. The tension-spicula are occasionally subfasciculated, or so numerous as almost to appear felted together; while in others they are dispersed singly, and rather sparingly distributed, crossing each other at various angles. These spicula are subject to considerable variation in form : all of them are more or less subclavate at the base, but their shafts exhibit the greatest amount of variation; some are quite attenuato-acuate, while others terminate so obtusely as to closely approach the cylindrical form; and gradational forms between the two extremes are of frequent occurrence. 'The bidentate equianchorate retentive spicula also exhibit very remarkable characters. There are two very distinct sorts of them-one comparatively large and of very robust structure, the other very minutely slender and delicate; both have their shafts semicircular. The larger ones average $\frac{1}{600}$ inch in length, with a diameter of shaft of $\frac{1}{3000}$ inch; the smaller series never appear to exceed $\frac{1}{1200}$ inch in length, and the shaft of one of the 
largest of them measured $\frac{1}{12 \theta 00}$ inch in diameter. In these smaller ones there also exists another peculiarity; and that is that the terminal teeth are given off at nearly right angles to the axis of the shaft. These peculiarities of the tension and retentive spicula of the dermal membrane, combined with the eccentric and singular form of the sponge, afford excellent specific characters to discriminate this from any other nearly allied species.

\section{HALICHONdRia VARIa, Bowerbank.}

Sponge massive, sessile, variable in form. Surface smooth or rough and rugged. Oscula simple, dispersed. Pores inconspicuous. Dermal membrane spiculous, reticulated; rete unispiculous; spicula acerate, stout, same size and form as those of the skeleton; retentive spicula bihamate, simple and contort, minute and slender, very numerous. Skeleton-rete compact, uni- or bispiculous; areas unsymmetrical; spicula acerate, short and stout. Interstitial membranes-retentive spicula bihamate, simple and contort, slender and minute, numerous.

Colour, in the dried state, dull ochreous yellow.

Hab. Straits of Malacca (Commodore Parish).

Examined in the dried state.

The external characters of this sponge are exceedingly variable. Sometimes it appears as a rough and irregular mass, full of small ridges and prominences; at other times it assumes the form of short cylindrical branches, with a surface comparatively smooth, and with the oscula well developed and evenly distributed. Notwithstanding these striking variations in form, the structural characters are exactly the same in every specimen. The most striking specific characters are exhibited in the dermal membrane, the unispiculous rete of which is a very beautiful object when mounted in Canada balsam. The rete is seldom more than one spiculum in width; and the areas vary to a very considerable extent in form; and the membranes filling the areas are in many cases crowded with the minute slender bihamate retentive spicula. These spicula are very small and slender, and require a power of about 300 linear to define them in a satisfactory manner. Their length does not exceed twice the diameter of a skeleton-spiculum.

The skeleton-rete is compact and strongly constructed, with but slight approaches to symmetry. The areas are very variable in form, and each side rarely ever exceeds one spiculum in length. The short stout acerate spicula of which it is formed are the same in length and form as those of the dermal rete. Within the mass of the sponge there are frequently to be seen interstitial cavities of comparatively considerable size; and in the lining membranes of these the minute bihamate retentive spicula abound to quite as great an extent as in the dermal membrane. I received several small specimens of this sponge from my friend Commodore Parish, who obtained them from the Straits of Malacca. 
Halichondria purpurea, Bowerbank.

Sponge massive, sessile. Surface very rough and rugged. Oscula simple, dispersed. Pores inconspicuous. Dermal membrane spiculous; tension-spicula fusiformi-acuate, rather slender, longer than those of the skeleton, very numerous; retentive spicula bidentate equianchorate, very minute, equable in size, numerous. Skeletonrete very coarse and open ; fibre multispiculous, very stout and compact; spicula fusiform acuate, short and stout. Interstitial membranes spiculous; spicula same as those of the dermis, dispersed, numerous. Sarcode dark purple.

Colour, in the dried state, dark purple.

Hab. Straits of Malacca (Commodore Parish).

Examined in the dried state.

Among the sponges from the Straits of Malacea which I received from my friend Commodore Parish, there was a specimen of a Sertularia, on which there were four spęcies of parasitical sponges located, and among them the one in course of description. It is a small mass about half an inch wide at the base, gradually decreasing in size, and terminating acutely at the height of $1 \frac{1}{4}$ inch, of a deeppurple colour. The surface is remarkably rugged, full of deep pits and sharp elevations. The dermal membrane is very characteristic of the species; it abounds in spicula ; the tension ones are frequently nearly twice the length of the skeleton ones, while they are very little more than half their diameter. They are very numerous, in some parts forming flat wide fasciculi, and in others they are scattered indiscriminately over the surface of the membrane. The retentive bidentate equianchorate ones are also very characteristic; they are slender and delicate in form, very equable in size, and very minute; they do not exceed $\frac{1}{1363}$ inch in length, or twice the diameter of a fully developed skeleton-spiculum, which measured $\frac{1}{2545}$ inch in diameter. Nearly the whole of these spicula, seen in situ, were firmly attached to the surface of the membrane by the middle of the convex back of the shaft. They were very numerous on some parts of both the dermal and interstitial membranes. Occasionally a few also of the short stout skeleton-spicula were mingled with the tensionspicula of both the dermal and interstitial membranes.

The skeleton-structure is remarkably coarse and strong, the fibre containing a far greater number of spicula than is usual in skeletors of the genus Halichondria, and the areas are wide and irregular in their form. These peculiarities of structure seem to indicate that this species attains a much greater size than the specimen under description. The whole of the internal sarcode, as well as the external portions of the sponge, are of a dark purple colour.

IsODICTYA RUDIS, Bowerbank.

Sponge massive, sessile. Surface rugged and very uneven. Oscula simple, dispersed, numerous. Pores inconspicuous. Dermal membrane abundantly spiculous ; tension-spicula acerate, long and slender, numerous, dispersed. Skeleton-texture coarse and irregular; pri- 
mary lines multispiculous ; secondary lines very irregular, mostly unispiculous, occasionally bi- or trispiculous ; spicula acuate, stout, and rather short. Interstitial membranes sparingly spiculous; spicula same as those of the dermis.

Colour, in the dried state, pale ochreous yellow.

Hab. Straits of Malacea (Commodore Parish).

Examined in the dried state.

The external characters of this species are by no means prepossessing. It is a rough and very uneven mass, 2 inches in length and about 1 inch in greatest diameter, full of ridges and depressions. Sections cut at right angles to the surface do not readily illustrate the characteristic structure of Isodictya, in consequence of the coarse and irregular nature of the skeleton; but on a more careful examination the presence of the stout continuous primary lines of the skeleton unmistakably lead us to a correct determination of the genus. The dermal membrane is very characteristic of the species. It is abundantly supplied with long, slender, acerate tension-spicula, irregularly distributed and crossing each other in every direction, These spicula are quite as long, and frequently longer, than those of the skeleton, while their diameter varies from half to one third of those of the last-named organs.

The skeleton-structure is very open and irregular, and the spicula in the primary fibres are very numerous; they are acuate and comparatively stout and short. The secondary lines are very irregularly distributed and rather numerous; so that when a section of the sponge is hastily examined, it is very liable to be mistaken for that of a Halichondria.

I received this species from my friend Commodore Parish, who obtained it from the Straits of Malacca.

Isodictya virgata, Bowerbank.

Sponge virgultose, more or less fistulous. Surface smooth. Oscula simple, dispersed, rather large. Pores inconspicuous. Dermal membrane spiculous; spicula acerate, same size and form as those of the skeleton, reticulated; rete rarely more than unispiculous or bispiculous, areas irregular in form ; retentive spicula bihamate, simple, and contort, rather numerous, minute. Skeleton diffuse and irregular; primary lines multispiculous, spaces between them varying from one to two spicula in width, rarely wider; secondary lines bior trispiculous, irregular. Interstitial membranes furnished abundantly with minute simple and contort bihamate retentive spicula, same as those of the dermis.

Colour, in the dried state, pale ochreous yellow.

Hab. Straits of Malacca (Commodore Parish).

Examined in the dried state.

This sponge consists of two short branches based on a small fragment of stone or coral; the tallest of the two does not exceed 2 inches in height, and about 2 lines in diameter; for a portion of its length there is a central fistulous cavity, but it does not appear at the 
distal extremities of the branches. The skeleton-structure of this species appears to be very irregular; but the well-produced primary lines of the skeleton unmistakably stamps it as an Isodictya. The rete of the dermal membrane is more or less irregular, and is, with its retentive spicula, very characteristic of the species. Its areas frequently exceed in width the length of a spiculum, and they vary to a considerable extent in form. The retentive spicula within them are in some of them rather numerous, while in others they are very sparingly distributed; they are very minute and slender, requiring a power of about 500 linear to render them distinctly to the eye. In the interstitial membranes the retentive spicula are very much more numerous than they are in the dermal one ; and they are especially so in the linings of the fistulous cavities.

It is very probable that hereafter this species will be found to attain a much greater altitude than the specimen in course of description. I am indebted to my friend Commodore Parish for my knowledge of it. He obtained it from the Straits of Malacca.

\section{Desmacidon rolioides, Bowerbank.}

Sponge ramous, branches inosculating. Surface smooth, but more or less spiniferous. Oscula simple, dispersed. Pores inconspicuous. Dermal membrane pellucid, spiculous, furnished with a leaf-like reticulation of minute acerate spicula. Skeleton-reticulating fibres compact and strong; areas wide and irregular. Spicula acerate, rather small and short. Interstitial membranes spiculous ; tensionspicula dispersed, same form and size as those of the dermis.

Colour, in the dried state, dull ochreous yellow.

Hab. Straits of Malacca (Commodore Parish).

Examined in the dried state.

This sponge and a small specimen of Geodia carinata are based together on a little sandy mass; they are so closely incorporated, and so nearly resemble each other in size, colour, and form, as to be readily mistaken by a hasty observer for one species only. The sponge-stem has an irregular expansion of $4 \frac{1}{2}$ inches length, and has an average diameter of about 4 lines; one portion of the branches is comparatively smooth, while another portion abounds in spinous projections.

The most strikingly distinctive character in this sponge exists in the dermal membrane. When a portion of it is mounted in Canada balsam and viewed with a linear power of about 100 , it exhibits an appearance exceedingly like that of a portion of the skeleton of a macerated leaf of Populus nigra. There are a series of veins or long: fasciculi composed of numerous minute acerate spicula meandering for considerahle lengths on the inner surface of the membrane; and the spaces between each of these are occupied by a very delicate uniserial network of minute spicula, simulating in a remarkable manner the leafy skeleton. The skeleton-rete is very open and irregular, and the fibre of which it is composed is very closely compacted; the acerate spicula of the skeleton are very much larger 
than those of the dermal membrane; but the whole of the spicula are rather small, requiring a power of about 300 linear to render their forms and proportions distinctly.

The interstitial membranes are abundantly supplied with acerate spicula irregularly dispersed, and of the same size as those of the dermis. I am indebted to my friend Commodore Parish for this interesting species. He obtained it from the Straits of Malacca.

\section{Desmacidon venusta, Bowerbank.}

Sponge sessile, fistulous; fistulæ comparatively large and open. Surface smooth and even. Oscula simple, within the fistulæ. Pores inconspicuous. Dermal membrane pellucid, abundantly spiculous, reticulated; rete unispiculous, very regular and beautiful; areas mostly triangular, rarely quadrangular; spicula acerate, short and stout, same size as those of the skeleton. Skeleton-rete very diffuse and irregular ; fibres slender and compact ; spicula small, short, and stout. Interstitial spaces filled with beautiful masses of unispiculous reticulated structure; spicula same as those of the fibrous skeleton; areas same size and form as those of the dermal membrane.

Colour pale ochreous yellow in the dried state.

Hab. Straits of Malacca (Commodore Parish).

Examined in the dried state.

This sponge consists of four short stout fistulæ, not quite an inch in height, the whole mass averaging about $1 \frac{1}{2}$ inch in breadth, and the parietes of the fistulæ are about $\frac{1}{8}$ of an inch in thickness. The structural peculiarities of the dermal membrane, when a small portion of it is mounted in Canada balsam and viewed with a power of about 100 linear, are remarkably regular and beautiful, and especially characteristic of the species. The rete consists of an elegantly symmetrical network of single spicula, with nearly the whole of the areas of a triangular form, a quadrangular one being of rather rare occurrence; and as the component spicula are very equal in their lengths and diameters, the result is a remarkable degree of symmetry and beauty. The whole of the interstitial spaces within the fibrous skeleton are filled with masses of a similarly regular and beautiful unispiculous reticular structure, closely simulating that of the dermal structure ; and amidst this beautiful tissue the long, slender, fibrous skeleton meanders in various directions. Although the structural characters of this species are few and simple, the regularity and beauty of the modes of their disposition afford excellent specific characters for its identification. The only species of Desmacidon with which it might possibly be confounded is $D$. folioides, from the same locality ; but, independent of the differences of external form, the last-named species differs in the dermal membrane being furnished with the peculiar leaf-like arrangement of its rete, and in the interstitial spaces; the spicula are only sparingly dispersed on the membranes. In both species the spicula are of about the same length ; but those of the species in course of description are twice the diameter of those of $D$. folioides. 
3. On the Form of the Trachea in certain Species of Storks and Spoonbills. By A. H. Garrod, B.A., F.Z.S., Prosector to the Society.

[Received March 15, 1875.]

No account of the peculiarities of the windpipe in Tantalus ibis and in Platalea ajaja has yet, to the best of my knowledge, appeared in print. They cannot but interest ornithologists ; I therefore append descriptions of them from specimens which have passed through my hands as Prosector to the Society.

In the Transactions of the Linnean Society* there is a paper by Mr. Joshua Brookes, F.R.S., "On the remarkable Formation of the Trachea in the Egyptian Tantalus." The author does not mention the sex of his specimen, and does not refer to the existence of any intrathoracic or any other loops; he draws attention only to the existence of a lateral compression of the portion of the trachea which is contained within the thorax; and he incidentally refers to the similarity of the arrangement of the windpipe in the Spoonbill and Tantalus ibis, but does not hint at the points in which they agree.

In most species of Ciconiidæ the only peculiarity of the windpipe is that the bronchi are longer than in other birds, the bifurcation of the trachea occurring at, or even a little above, the superior aperture of the thorax. This condition I have observed in the female Ciconia boyciana which died on January 15th, 1874, as well as in examples of C. maguari and C. alba. In the male of C. nigra the bronchi are known to be peculiarly long $t$, and to form an $\Omega_{2}$-shaped curve entering the lungs. No other peculiarities have been described among these birds.

A specimen of Tantalus ibis was purchased by the Society on the 26 th of May, 1873, which died on the 12th of March, 1875. It proved to be a male. The following is the arrangement of the convolutions of its trachea (see figure, p. 298). The windpipe descends the neck in front of the osophagus without any peculiarities being observable, the rings which go to compose it being exactly like those of other allied birds, circular, complete, elastić, notched in the middle line before and behind, and of ordinary depth. Directly it reaches the superior aperture of the thorax, between the two rami of the furcula, a sudden change occurs. The succeeding rings are inelastic, from being ossified; and they are ossified together in pairs, so that their apparent depth is more than double that of the cervical rings, the intermediate membrane being included in the double rings. The depth of the unmodified rings is hardly more than $\frac{1}{12}$ of an inch, that of the intrathoracic modified ones being as much as $\frac{1}{4}$ of an inch. The diameter of both is about $\frac{1}{3}$ of an inch; those in the chest are further peculiar in developing a slight median longitudinal ridge along their posterior surface.

The two musculi depressores trachea, after running down the

* Vol. xvi. p. 499.

† Naumann's Naturgeschichte der Vögel Deutschlands, vol. ix. p. 229. 
Fig. 1.

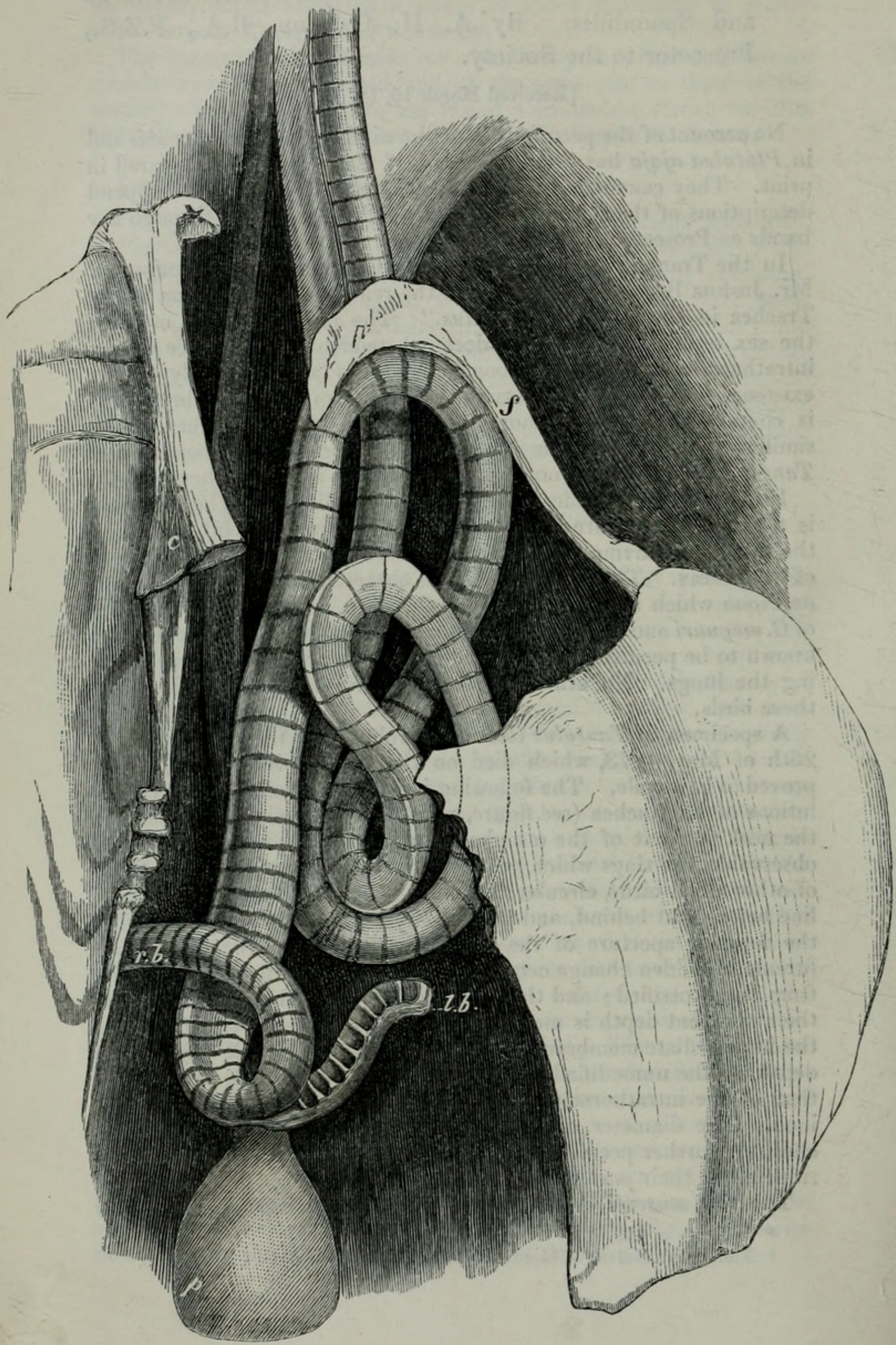

Intrathoracic convolutions of the trachea in Tantalus ibis.

$c$, coracoid; $f$, furcala ; $p$, proventriculus ; $r . b$, right bronchus; $l . b$, left bronchus; st, sternum. 
windpipe as long as it is in the neck, leave it together as it enters the chest to run to their insertions behind the sternal articular ends of the second complete ribs, the left one crossing in front of the upper of the two loops described below. There are no special lateral muscles running to the syrinx.

The trachea, modified in the manner above described, continues its normal course downwards as far as a horizontal plane cutting the base of the heart, when it makes a fairly gradual turn through half a circle, directly forward, to consequently ascend with the posterior keel above mentioned, running along the middle of its convex surface. On reaching the level of the symphysis furculæ it makes a second semicircular turn to the right, to again descend nearly as far as on the former occasion, and making a third similar turn to the left whilst in the fold of the first loop, ascends a third time as high as the line joining the two sides of the furcula-in other words, to the very top of the thoracic cavity. Here it turns backwards to descend again, in contact with the first part of the intrathoracic tube, to its right side, as far as the level of the apex of the heart and the commencement of the proventriculus; where, making a short very abrupt turn forwards, it bifurcates into the two bronchi, which therefore, uniquely, run from their origins upwards and outwards to their respective lungs. In this third and last descending portion of the windpipe, which has a length of $5 \frac{1}{2}$ inches, the lower 3 inches are considerably flattened in what would be the lateral direction, which, through the convolutions it has been called upon to make, is twisted, so that the flattening appears to be nearly antero-posterior, the median ridge, developed posteriorly, being placed considerably on the right side.

About an inch above this flexure, in which the bronchi bifurcate, the previously deep double rings suddenly cease to be developed as such, and return to their normal condition just before the peculiarly situated and simple syrinx is reached.

There are altogether 82 of the ossified double rings in the modified portion of the windpipe.

The earlier bronchial rings are peculiar in being deep, the fibrocartilaginous rings being ossified and thickened above and below for a certain portion (the external) of their circumference.

Platalea ajaja.-The peculiar convolution, within the thorax, of the trachea in Platalea leucorodia is well figured by $\mathrm{Mr}$. Yarrell *. The arrangement in Platalea ajaja is, however, quite different. A pair of these birds was purchased by the Society on the 13th of August, 1870. The female dying on the 27 th of July, and the male on the 13th of October, 1873, have given me the opportunity of examining the windpipe in both sexes. The trachea is simple, straight, of uniform calibre, and peculiarly short, extending only two thirds down the length of the neck, where the uncomplicated syrinx is situated and the bifurcation of the bronchi occurs. The usual pair of muscles, one on each side, runs to this syrinx from above, and ceases there. The bronchi are fusiformly dilated at their commence-

* British Birds, vol. ii. p. 504. 
Fig. 2.

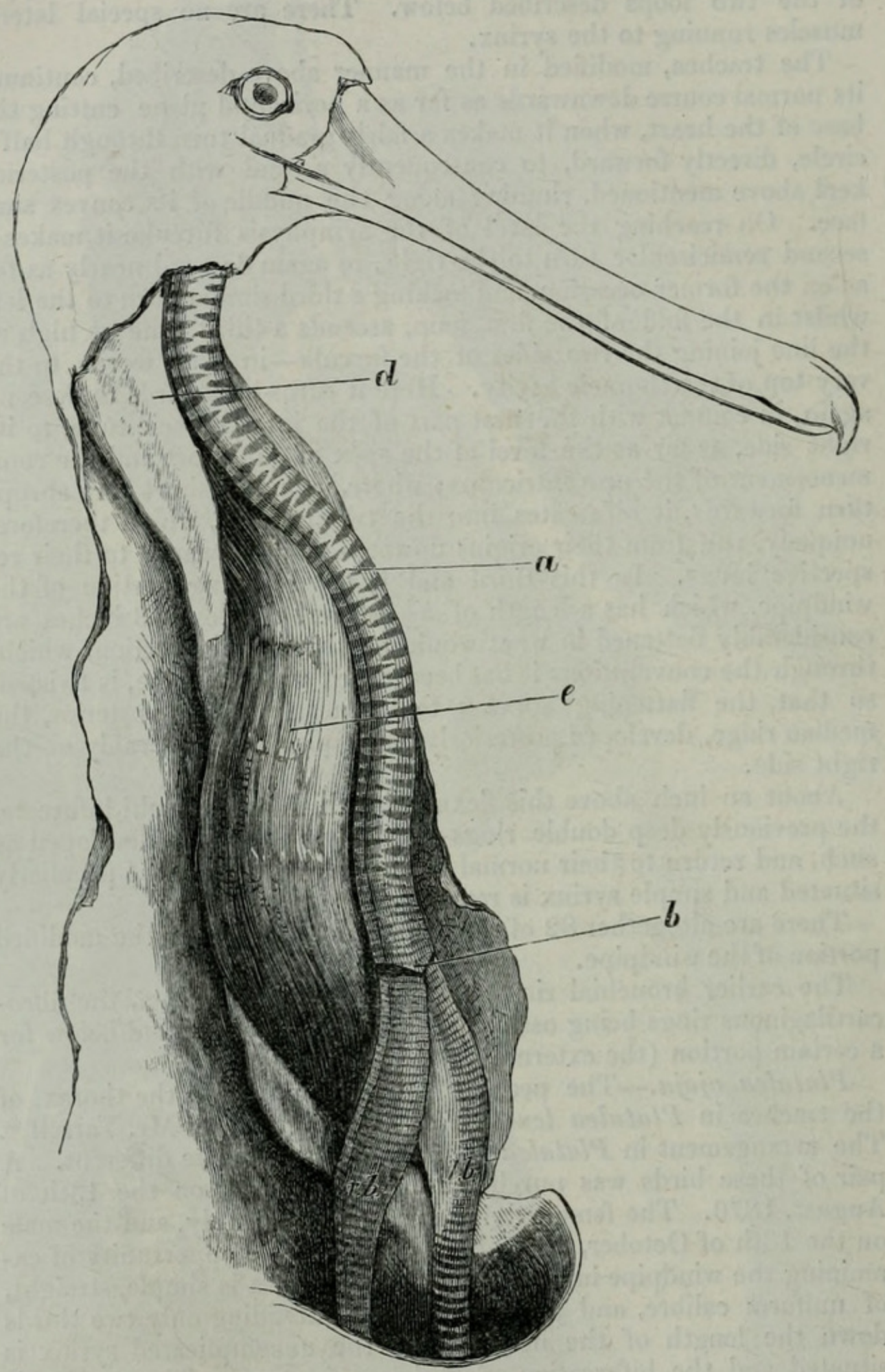

Cervical bifurcation of the bronchii in Platalea ajaja.

$a$, trachea $; b$, syrinx ; $d$, œsophagus ; $e$, cervical muscles and vertebræ ; $r . b$, right bronchus; $l . b$, left bronchus. 

P.Z.S. 1875.PI.XLI
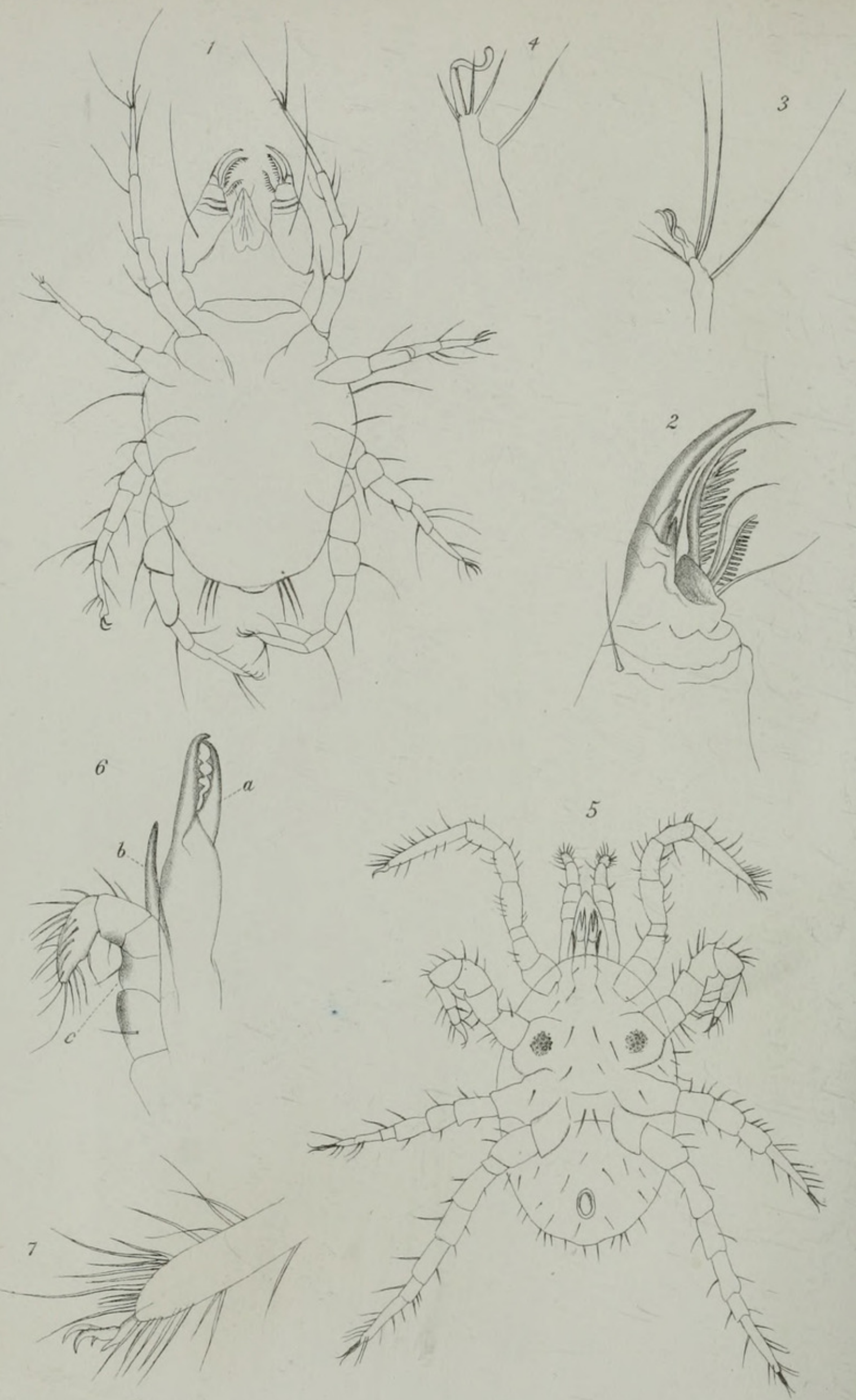


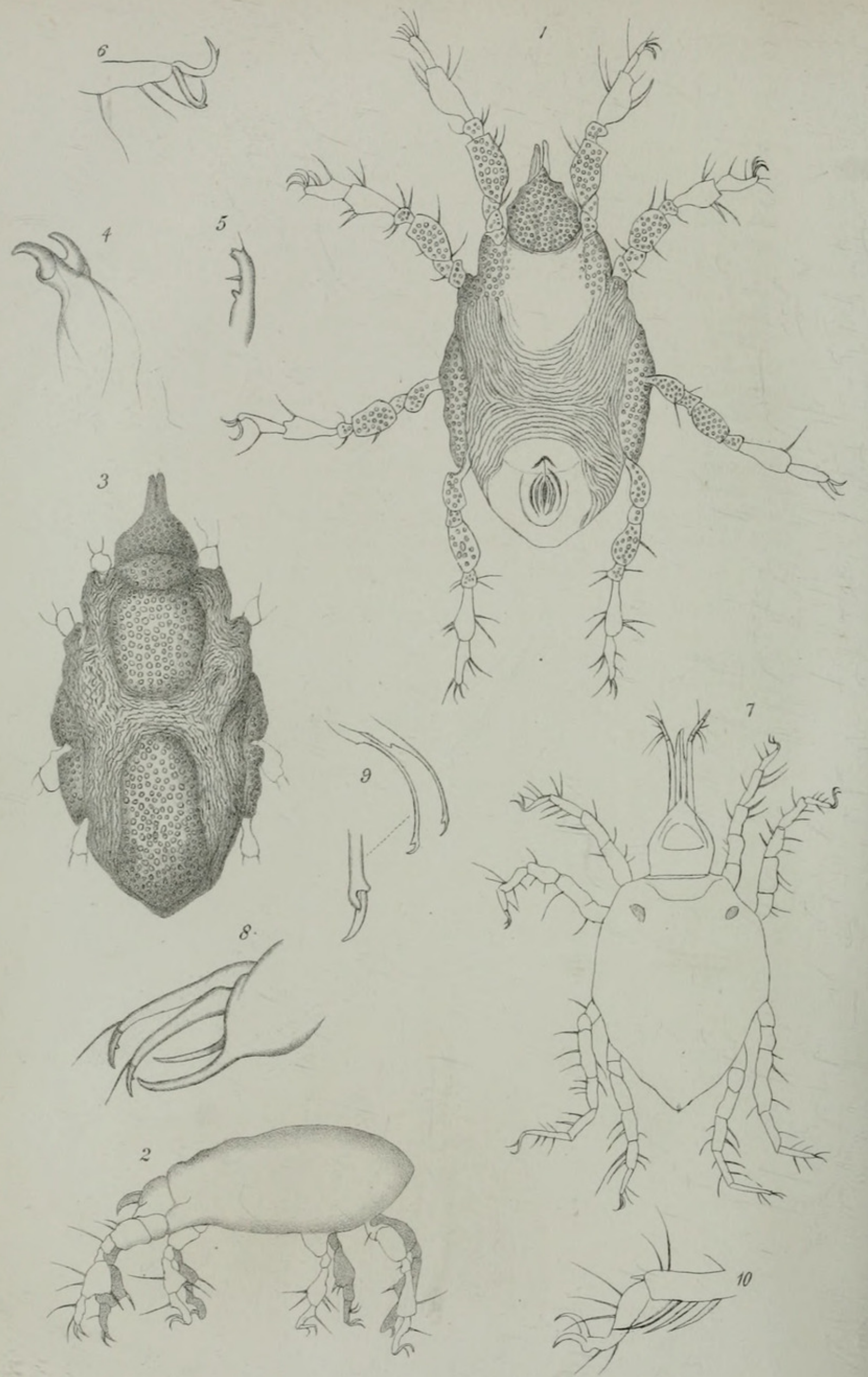
ment, where the rings which encircle them are not complete, a membrane taking their place in that portion of each tube which is contiguous to its opposite neighbour. Each bronchus, lower down, is composed of complete cartilaginous rings (vide fig. 2, p. 300).

By many ornithologists Tantalus is arranged along with Platalea and Ibis, instead of with the Storks. Nitzsch, in his 'Pterylography,' places it with Ciconia in his group Pelargi, separating off Platalea and Ibis to form the Hemiglottides. In the "Revised List" of the Animals in the Society's Gardens, Mr. Sclater adopts the same arrangement. In my paper "On the Nasal Bones of Birds" *, it is mentioned that Platalea and Ibis are schizorhinal-that is, have the external osseous nares split up in a manner there described, in which point they differ from the rest of Prof. Huxley's Pelargomorphæ, and therefore from Tantalus.

There are many other structural peculiarities which make it perfectly certain that Tantalus is a member of the Ciconiidæ, and not an aberrant one either. Some of the most important it will not be out of place to mention here. They will be most easily appreciated in a tabular form, as thus represented :-

In Ibis and Platalea.

The skull is schizorhinal.

The angle of the mandible is produced and recurved.

The pectoralismajor muscle is simple, not being separable into distinct layers.

The accessory femoro-caudal muscle is well developed.

The semitendinosus muscle is muscular throughout.

A small muscular belly is sent from the biceps cubiti to the tendon of the tensor patagii longus muscle.
In Ciconia and Tantalus.

The skull is holorhinal.

The angle of the mandible is truncated.

The pectoralis major muscle is in two layers, a superficial and a deep, easily separable one from the other.

The accessory femorc-caudal muscle is absent.

The semitendinosus muscle is tendinous for its distal half.

No slip leaves the biceps cubiti muscle to join the tensor patagii longus.

4. A Review of the British Marine Mites, with Descriptions of some new Species. By George Stewardson Brady, C.M.Z.S.

[Received March 16, 1875.]

\section{(Plates XLI. \& XLII.)}

The marine Mites hitherto described either by British or foreign authors are very few in number; and the descriptions seem for the most part to have been based on the observation of but few individuals, often only one or two for each species. The animals have

\footnotetext{
* P. Z. S. 1873 , p. 33.
} 
usually been detected creeping on the stems of seaweeds or zoophytes or on the sides of marine aquaria; and to catch them in this fashion has doubtless the great advantage of presenting the creatures alive, so that their motions and habits, as well as the anatomical details of such delicate organs as those of the mouth, which are of course in active operation during life, may be more readily observed. My own knowledge of the Mites however, is, derived almost entirely from the examination of dead specimens ; for though I have often found them living plentifully under stones and in the crevices of rocks on the sea-shore, the method of capture which I adopt has always killed them. The little animals are very active, running with great agility; and as a sudden nip of the forceps would most likely mutilate them so much as to render them useless for examination, I have usually when collecting dropped a little spirit from a full camel's hair pencil over the retreating speck and so brought its movements to a stand-still for a time sufficient to allow of his imprisonment : possibly if put into sea-water at once he might in some cases recover the temporary shock of the spirit bath, inasmuch as I have seen one species (Pachygnathus seahami) retain its vitality even after an immersion of many hours in a pretty strong arsenical solution, and I have also noticed that two or three drops of proof spirit does not always suffice to arrest the movements of the Acari over stones or seaweed. The great majority of my specimens, however, have been obtained from the washings of material dredged in depths of several fathoms, and have not been observed until after prolonged immersion (in spirit) and death.

In some dredgings made off the coasts of Durham and Yorkshire, the number of individuals was very considerable, almost leading one to the belief that they must in favourable spots colonize the mud almost as thickly as their better-known relatives a decaying cheese.

The only British naturalists who have written on the marine Mites are, so far as I know, Allman, Gosse, and Hodge.

The first-named author described a species (Halarachne halichori) parasitic in the nostrils of a Seal. Mr. Gosse, in the 'Annals and Magazine of Natural History,' described and figured, with his characteristic accuracy and fidelity, three species, Halacarus rhodostigma, H. ctenopus, and Pachygnathus notops. More recently $\mathrm{Mr}$. Hodge named and described, in the 'Transactions of the Tyneside Naturalists' Field Club,' species which he believed to be new, but some of which must, I fear, be considered spurious; his species were Pachygnathus seahami and P. minutus, Leptognathus falcatus, Halacarus granulatus and $H$. oculatus. I have myself taken all these in greater numbers than fell to the lot of Mr. Hodge, and have likewise been able to examine the type specimens, which, with the rest of his collection, are now preserved in the Newcastle Museum. The additions which $I$ have been able to make in this paper are the following:-Trombidium fucicolum, Pachygnathus sculptus, Gamasus marinus, and Cheyletus robertsoni.

Mr. Gosse mentions that Fabricius has described two Norwegian marine mites, Acarus zosterce and $A$. fucorum; but these seem to 
be distinct from any thing at present known to us in Britain. The same author says also, on the authority of M. Paul Gervais, that M. Dujardin " had described a marine Oribates in the 'Journ. de l'Institut,' for 1842,"' but he was unable to verify the quotation.

Besides these, the only marine Acari of which I have found notices are Thalassarachna verrillii, described by Dr. A. S. Packard in the 'American Journal of Science and Arts,' vol. i. 1871, and Pontarachna punctulatum, Philippi, in Wiegmann's 'Archiv,' vol. vi. p. 191, 1840 , pl. iv. figs. 4,5 .

I have not thought it necessary to reproduce in extenso the descriptions of previously known species, but have contented myself with noting their more important characters, combining my own observations with those of prior authors.

\section{Class ARACHNIDA.}

\section{Order A C A R I N A.}

Fam. Trombidiade.

Genus Trombinium, Fabr.

Trombidium (?) Fucicolum, nov. sp.

Length $\frac{1}{30}$ of an inch: colour very dark brown, opaque; body tumid, tapered and pointed in front, broadly rounded behind, produced laterally into two angular promontories at the origins of the first and second pairs of legs; surface corrugated. Mandibles consisting of two triangular plates (?) opposing each other in the median line; palps small, obtuse, 4 - or 5 -jointed, the penultimate joint bearing a small appendage something like an obsolescent unguis. Thighs not distant, all the pairs of legs having origin toward the front of the body. Legs 5-jointed, stout, opaque; second and fourth joints much the longest, first and third shortest ; last joint terminating in three falciform claws, one of which is more slender than the rest, bearing near the extremity of the inner margin two short and stout spines, and beset with several (10-12) long slender hairs.

One adult and one young specimen of this species were washed from among the roots of Algæe gathered between tide-marks in Roundstone Bay, Ireland, by Mr. David Robertson. I am not sure that it is rightly referred to the genus Trombidium; but it seems to agree with Dugès's definition in most respects. The animal was so much mutilated in the process of examination that $I$ have not been able to give a perfect figure, nor have I succeeded in getting a satisfactory view of the mouth-apparatus.

\section{Genus Pachygnathus, Dugès.}

Pachygnathus notops, Gosse, Ann. \& Mag. Nat. Hist. ser. 2, vol. xvi. (1855), pl. 8. figs. 1-4.

"Body flat, sinuated, pointed behind, black; one eye on the back ; legs equal, the first and second remote from the third and fourth, hairy ; the last joint the longest.

" Length $\frac{1}{87}$ of an inch. Body lozenge-shaped or somewhat 7- 

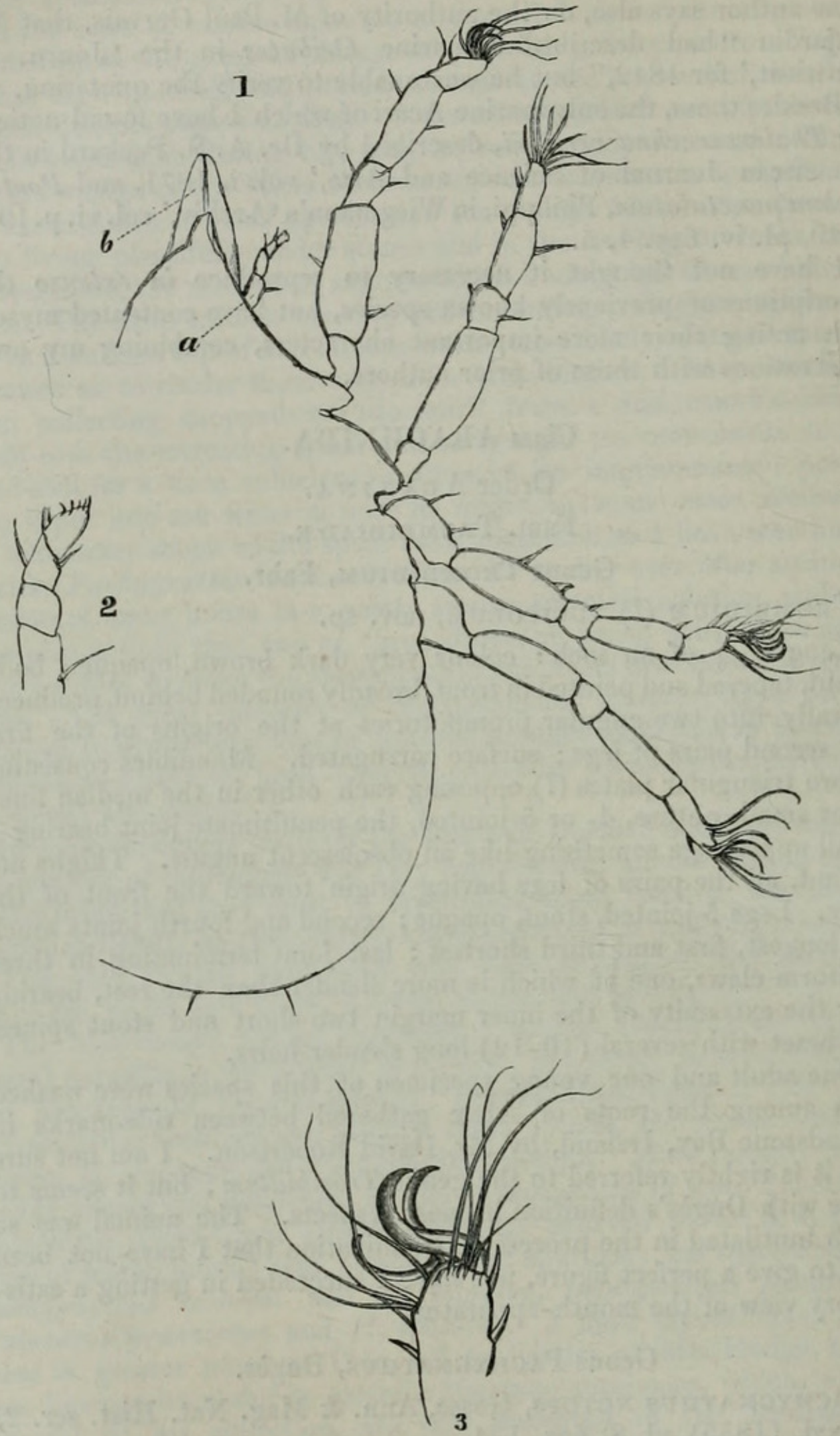

Trombidium fucicolum.

Fig. 1. Right half of animal, magnified about 100 diameters. $a$, palp; $b$, mandibular plates.

2. Palp, more highly magnified.

3. Extremity of foot, more highly magnified. 
sided, with sinuations at the origin of the limbs; it is hyaline and colourless at the margins; but the interior is almost filled with a flesh of deep blue-black hue, perfectly opaque, and of defined, subregularly sinuous outline. In the centre of the back, just behind the head, is a bright ruby-like round eye, placed in front of the opacity and between the first legs.

"The head, formed by a great lip, projects in front and carries two small palpi, thick at the base, conical and pointed. Below, the lip is divided longitudinally, each half being slightly incurved and pointed, the two divisions approaching in a pincer-like manner. Under slight pressure there were projected between the palpi two slender styles, which doubtless represent the mandibles; and hence I am not sure whether the species should not range under the genus Raphignathus of Dugès.

"The legs are about equal and alike; the fourth and sixth joints are large and swollen; the seventh is the largest and tapers abruptly at the middle like a claret-bottle ; the tip forms a little round disk, whence diverge a pair of curved hooks, with plain edges, but twotoothed at the tip, or rather having a prominent tooth over the tip.

"All the joints are well furnished with straight bristles, the sixth having one much longer and stouter than the rest. The limbs are set in two series, the first and second originating close together, but remote from the third and fourth, which are also contiguous to each other."

Not having seen any undoubted specimen of this species, I have transferred Mr. Gosse's description, which was drawn from specimens taken at Ilfracombe.

Mr. Norman notes it as being " abundant on weeds in rock-pools, Balta Sound, Shetland."

Pachygnathus seahami, Hodge, Trans. Tyneside Nat. F. C. vol. iv. p. 319 , pl. xvi. figs. l $a, b, c$.

This species agrees in every respect with the foregoing, except in the structure of the claws, which are angularly bent and finely ciliopectinate on the inner margin. It may perhaps be doubted whether it ought to rank as a distinct species, though Mr. Gosse appears to have been disposed to think so, after having seen Mr. Hodge's specimens. The type specimens were taken on the Durham coast; and I have myself found it plentifully on weeds between tide-marks at Sunderland, in the Scilly Islands, and on the west coast of Ireland.

Pachygnathus minutus, Hodge, Trans. Tyneside Nat, F. C. vol. iv. p. 301, pl. xvi. figs. 10,11 .

Length $\frac{1}{90}$ of an inch : colour reddish brown; shield truncate at insertion of first legs. Rostrum a stout bulb, tapering abruptly, and terminated by two lip-like organs; legs short and stout, the third and fifth joints swollen, sixth tapering abruptly and terminating in two falcate claws, which have a small tooth on the outer edge; between the claws a small hook. Eye single, situated behind the rostrum. Body minutely corrugated and pitted, Legs three pairs,

Proc. Zool. Soc.-1875, No. XX. 
The single specimen on which Mr. Hodge founded this species was taken on a stem of Coryne eximia from between tide-marks; and there can be little doubt, from the fact of its possessing only three pairs of legs, that it is merely the young of some other species. The specimen, moreover, which is now in the Museum of the Natural-History Society at Newcastle-upon-Tyne, has in other respects the appearance of immaturity, the surface-markings and different areas of the body being very imperfectly defined. I strongly suspect that it may prove to be an early stage of the following species.

Pachygnathus sculptus, nov. sp. (Plate XliI. figs. 1-6.)

Length $\frac{1}{45}$ of an inch : colour reddish brown. Body oblongovate, deeply indented at the origin of the limbs. The head forms a wide bulbous projection, from which springs a rather short and thick mucronate rostrum. The mandibles and palps are both poorly developed, the latter being short, thick, and terminating in small claws, the former consisting each of a short, slightly curved stem, which is furnished with two small setæ and a wart-like tooth on the concave margin. The two hinder pairs of legs are rather longer and more slender than the rest; thighs distant, being inserted near the margins of the body; second and fourth joints of the legs very small and constricted; third and fifth (especially in the first two pairs) larger and much swollen; first joint small in the two anterior pairs, rather longer in the two posterior; last, or sixth, joint of moderate length, suddenly tapering from the middle and terminating in two falcate claws, each with a small tooth on its convex margin. The dorsal surface of the body is mapped out into several distinct areas, characterized by pitted and corrugated systems of sculpture : the head and rostrum form an area bounded by a convex line, which stretches between the origins of the first pair of feet: immediately behind, and separated only by a lateral indent, is a subquadrate plate, broad in front and rather narrowed at its posterior extremity, which coincides with the middle of the body; behind this plate again, and separated from it by a narrow isthmus of corrugated epidermis, comes another elongated shield-shaped plate, which stretches quite to the hinder extremity of the body, increasing in width posteriorly : these three areas are all covered with closely set circular pittings, and are divided from each other by spaces of wrinkled epidermis, the lines of which are somewhat waved and irregular, but run generally in a concentric manner round the dotted shields : on the lateral aspects of the body also are two pitted areas, one vaguely defined and embracing the origins of the first and second pairs of legs, chiefly on the inferior surface of the body, the other having very distinct boundaries and extending almost equally on the upper and lower aspects of the body, from midway between the second and third pairs to the origin of the fourth pair of legs. The ventral surface of the body is chiefly corrugated, the head, however, being distinctly pitted as on the dorsal aspect; a space corresponding with the dorsal thoracic shield has no perceptible 
sculpture, as also a similar space situated posteriorly and surrounding the anus. The first, second, third, and fourth joints of the legs are also marked with pitted sculpture.

Several specimens of $\boldsymbol{P}$. sculptus were dredged in 25-35 fathoms, in various localities off the coasts of Durham and North Yorksnire.

\section{Genus Raphignathus, Dugès.}

\section{(Leptognathus, Hodge.)}

Raphignathus falcatus (Hodge). (Plate XLII. figs. 7-10.)

Leptognathus falcatus, Hodge, Trans. Tyneside N. F. C. vol. v. p. 302 , pl. 16. figs. 6,7 .

Length $\frac{1}{28}$ of an inch : colour orange-brown. Body truncate above insertion of first legs. Head forming a broad subtriangular bulbous projection, from the front of which stands out a long, slender, bifid rostrum, between the valves of which, by pressure or dissection, may be discovered two slender, curved, unguiculate and protrusile mandibles. Palps very long and slender, extending beyond the tip of the rostrum, and bearing towards the extremities a few fine setæ. Legs of moderate and nearly equal length; the joints not much differing in size, except the last, which is long, thin, and terminated by two simple claws; thighs remote. Eyes three, one behind the base of the head, the others near the origin of the second pair of legs, Upper surface of the body divided by delicate furrows or striæ into four symmetrically arranged areolæ-two lateral, one anterior, and one posterior.

I have not been able thoroughly to satisfy myself as to the anterior eye spoken of by Mr. Hodge. I can find no trace of it in his type specimen; but I think I can detect something like it in one of my own. However, Hodge's description is so circumstantial that I conclude it must have been plainly visible in the fresh state of his specimen. I think there can be little doubt that the species is properly referable to the genus Raphignathus of Dugès.

Mr. Hodge's specimens were taken on the Durham coast in depths of from 20 to 30 fathoms. Several examples have been more recently dredged by $\mathrm{Mr}$. David Robertson and myself on the same coast and also amongst the Scilly Islands in a depth of 10-12 fathoms.

Fam. Gamasida.

Genus Gamasus, Latreille.

Gamasus marinus, nov. sp. (Plate XLI. figs. 5-7.)

Length $\frac{1}{12}$ of an inch: colour yellowish brown. Body regularly oval, beset with scattered hairs; thighs contiguous, springing from near the median line. The palpi are large and thick, 6 -jointed, obtuse, recurved at the extremity, the last joint thickly beset with rather long hairs : the mandibles are (in the adult) longer than the palps, and end in two strong denticulated nipping-claws like those of the hand of a lobster; externally, between them and the palps, 


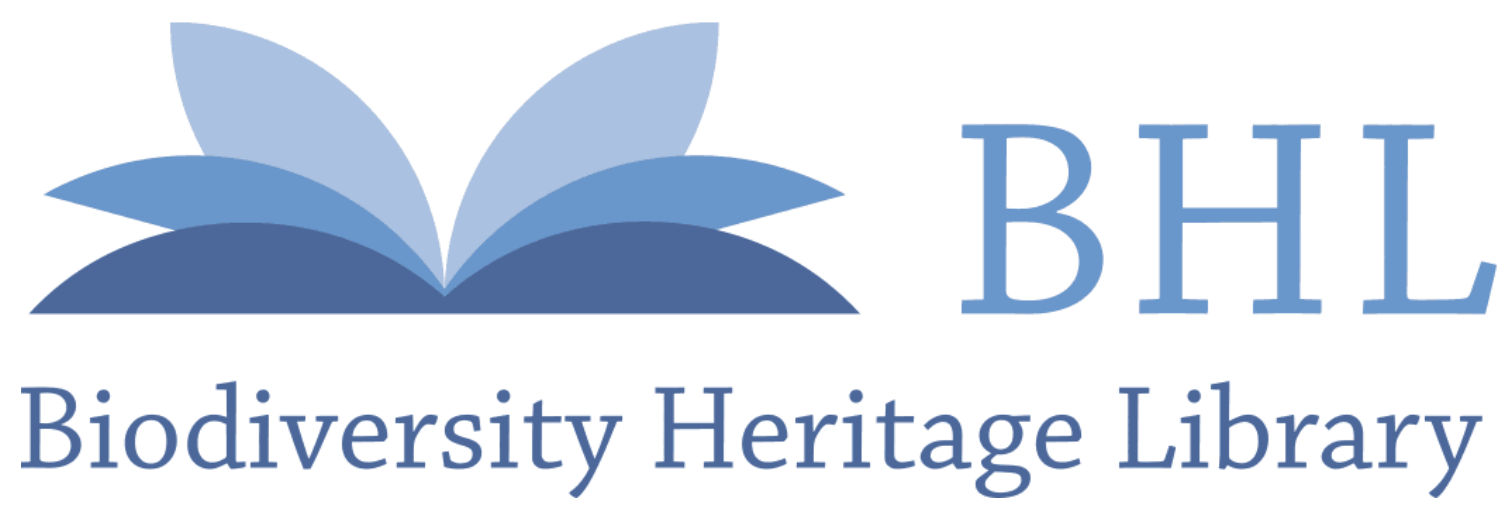

Hamilton, Edward. 1875. "April 6, 1875." Proceedings of the Zoological Society of London 1875, 269-315. https://doi.org/10.1111/j.1469-7998.1875.tb00519.x.

View This Item Online: https://www.biodiversitylibrary.org/item/90418

DOI: https://doi.org/10.1111/j.1469-7998.1875.tb00519.x

Permalink: https://www.biodiversitylibrary.org/partpdf/73632

\section{Holding Institution}

Natural History Museum Library, London

\section{Sponsored by}

Natural History Museum Library, London

\section{Copyright \& Reuse}

Copyright Status: Public domain. The BHL considers that this work is no longer under copyright protection.

This document was created from content at the Biodiversity Heritage Library, the world's largest open access digital library for biodiversity literature and archives. Visit BHL at https://www.biodiversitylibrary.org. 